\title{
Innovations in applications and prospects of bioplastics and biopolymers: a review
}

\author{
Sonil Nanda ${ }^{1}$ Biswa R. Patra ${ }^{2} \cdot$ Ravi Patel $^{2} \cdot$ Jamie Bakos $^{1} \cdot$ Ajay K. Dalai $^{2}$ (i) \\ Received: 23 August 2021 / Accepted: 23 September 2021 / Published online: 29 November 2021 \\ (c) The Author(s), under exclusive licence to Springer Nature Switzerland AG 2021
}

\begin{abstract}
Non-biodegradable plastics are continually amassing landfills and oceans worldwide while creating severe environmental issues and hazards to animal and human health. Plastic pollution has resulted in the death of millions of seabirds and aquatic animals. The worldwide production of plastics in 2020 has increased by $36 \%$ since 2010 . This has generated significant interest in bioplastics to supplement global plastic demands. Bioplastics have several advantages over conventional plastics in terms of biodegradability, low carbon footprint, energy efficiency, versatility, unique mechanical and thermal characteristics, and societal acceptance. Bioplastics have huge potential to replace petroleum-based plastics in a wide range of industries from automobiles to biomedical applications. Here we review bioplastic polymers such as polyhydroxyalkanoate, polylactic acid, poly-3-hydroxybutyrate, polyamide 11, and polyhydroxyurethanes; and cellulose-based, starch-based, protein-based and lipid-based biopolymers. We discuss economic benefits, market scenarios, chemistry and applications of bioplastic polymers.
\end{abstract}

Keywords Bioplastics $\cdot$ Biopolymer $\cdot$ Biodegradability $\cdot$ Carbon footprint $\cdot$ Sustainability $\cdot$ Bioeconomy

$\begin{array}{ll}\text { Abbreviations } \\ \mathrm{ASTM} & \text { American Society for Testing and Materials } \\ \mathrm{CO}_{2} & \text { Carbon dioxide } \\ { }^{\circ} \mathrm{C} & \text { Degree Celsius } \\ \mathrm{ISO} & \text { International Organization for Standardization } \\ \mathrm{kg} & \text { Kilogram } \\ \mathrm{MJ} / \mathrm{kg} & \text { Megajoules per kilogram } \\ \mathrm{MJ} & \text { Megajoules } \\ \mathrm{MPa} & \text { Megapascal } \\ \mathrm{mm} & \text { Millimeter } \\ \% & \text { Percent } \\ \mathrm{USD} & \text { United States Dollar } \\ \mathrm{wt} \% & \text { Weight percent }\end{array}$

Ajay K. Dalai

ajay.dalai@usask.ca

1 Titan Clean Energy Projects Corporation, Craik, SK, Canada

2 Department of Chemical and Biological Engineering, University of Saskatchewan, Saskatoon, SK, Canada

\section{Introduction}

Plastics are an indispensable part of modern society with numerous everyday applications in a wide range of industries, commerce, packaging and household. Plastics have countless social benefits in our daily lives. The population growth, economic progress, demand for commodities and lifestyle changes are remarkably increasing the demand and production of plastic products. Tremendous amounts of plastic wastes are generated in both developing and developed countries. Polyethylene, namely high-density polyethylene and low-density polyethylene, polyethylene terephthalate, polyvinyl chloride, polystyrene and polypropylene constitute a huge percentage of the total plastic production at a global scale. Global plastic production has increased significantly over the years. For example, in 2019, the worldwide plastics production was 368 million tonnes compared to 245 million tonnes in 2008 (Fig. 1). New estimates reveal that nearly 1.6 million tonnes/day of plastic wastes are generated globally due to the COVID-19 pandemic outbreak in the form of single-use surgical facemasks, face shields, syringes, latex or nitrile gloves, medical gowns, shoe covers, sanitizer containers (Benson et al. 2021). For instance, the disposal of single-use facemasks and face shields surpasses 3.4 billion worldwide every day because of the COVID-19 pandemic. Although the global plastics production slightly decreased 


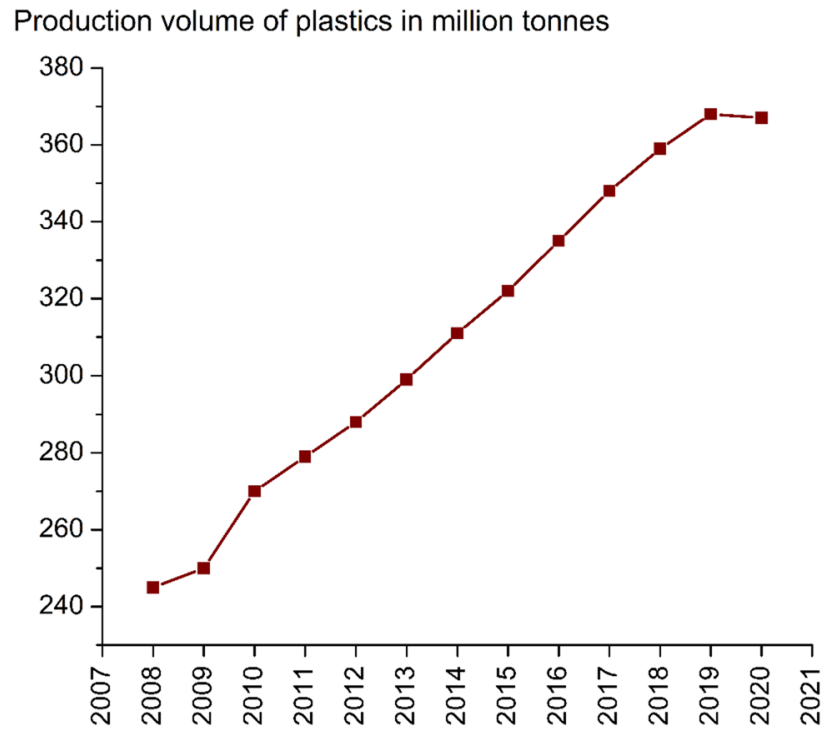

Fig. 1 Global production of plastics (Data source: Statista 2020). The production of plastics in 2020 has increased by $36 \%$ since 2010 . There was a slight decline in plastics production in 2020 because of the unprecedented impacts of the COVID-19 pandemic on the world economy

in 2020, its demand increased by $40 \%$ along with the generation of plastic wastes in the form of medical waste and personal protective equipment by $370 \%$ (Gorrasi et al. 2021). Plastics are industrially and commercially attractive owing to characteristics like lightweight, durability, flexibility, low production cost, easy availability and mass production.

Synthetic polymers have many industrial and household applications. In the packaging industry, alternative materials to replace plastic are hard to seek because of some exceptional and unparalleled characteristics. Microplastics, typically having a length of $<5 \mathrm{~mm}$, are more concerning in terms of soil, water and air pollution due to their smaller size, which can penetrate the food web through aquatic organisms, animals and humans ( $\mathrm{Li}$ et al. 2016; Padervand et al. 2020; Naqash et al. 2020; Chia et al. 2021). A recent report also suggests that for the first time, microplastics are detected in the placentas of unborn babies, which is a matter of great concern (The Guardian 2020). A recent study by Mu et al. (2021) has revealed that exposure of zebrafish to polystyrene microplastics imparted changes in their behavioral patterns such as lessened activity and moving distance. Although the knowledge of microplastics in freshwater is in its infancy, several treatment methods for its removal are available such as filtration, sorption, chemical processes, as well as biological exclusion and ingestion (Razeghi et al. 2021). Plastic waste components are a complex mixture of both macro-molecular contaminants such as polymeric compounds as well as micro-molecular contaminants such as additives and monomeric compounds (Vethaak and Leslie
2016; Wang et al. 2019). Plastic products are either fully or partly synthetic, brittle or fragile and prone to breakdown into small fragments upon exposure to ultraviolet light, direct sunlight or visible light ( $\mathrm{Li}$ et al. 2016; Tofa et al. 2019).

The indispensable use of plastics in our modern life has significantly increased their waste accumulation, thus making their disposal and recycling prime waste management issues. Plastics constitute a major non-degradable portion of municipal solid waste (Nanda and Berruti 2021a). Additionally, most of the plastics waste ends up in landfills, soil, oceans and water bodies, thus creating hazards for plants, terrestrial and aquatic animals and humans. Pollution by plastics has resulted in the death of more than 1 million seabirds and 100,000 sea animals globally (Othman et al. 2021). Conventional petrochemical-based plastics are nonbiodegradable because of which they last in landfills and oceans for thousands of years, thus affecting soil quality, microbial activity, flora and fauna. However, the overuse of petrochemically derived plastics, rubbers and synthetic polymers along with their inferior recycling techniques has made their remediation more difficult (Nanda et al. 2019; Nanda and Berruti 2021c). Alternative and sustainable methods for recycling or valorizing plastic wastes should be established instead of their pervasive disposal into landfills and oceans.

Plastics wastes can be potentially diverted from landfilling to waste-to-energy conversion technologies to generate solid, liquid and gaseous biofuels for supplementing the augmenting energy demands and addressing climate change (Fawzy et al. 2020; Suresh et al. 2021; Nanda et al. 2021; Nanda and Berruti 2021b). The effective solution for plastic waste management is proper recycling. However, the high heterogeneity, recalcitrance and cross-contamination of plastic wastes with organic matter and inert materials typically make thermochemical processing costly and energyintensive. Incineration of municipal solid waste containing around $12 \%$ of mixed plastic waste has been reported to be a primary factor for air pollution, as well as toxic and greenhouse gas emissions (Verma et al. 2016). Direct incineration of municipal solid waste enriched with plastic wastes also releases toxic pollutants such as furans, dioxins, polychlorinated biphenyls and mercury into the environment (Verma et al. 2016). Additionally, the combustion of plastic products made up of polyvinyl chloride such as plumbing pipes, mainly used in agriculture and household purposes, has the potential to liberate harmful halogenated compounds upon thermal degradation. The incineration of plastic waste potentially increases the risk of pulmonary and cardiac diseases, respiratory ailments, nausea, headaches, skin rashes, cancer, birth defects, endocrine disruption, compromised immunity and severe damage to the nervous and reproductive system in humans (Rustagi et al. 2011). 
Dioxins generated from the incinerated waste plastic settle on the crops and water bodies eventually entering our human food chain through the consumption of contaminated food and water. The prevailing effects of leached toxins from plastic waste are widespread to humans and animals through ingestion or inhalation (Vethaak and Leslie 2016). Additionally, smaller and larger particles of plastics can act as a substrate that can carry pathogenic microorganisms, parasites and hazardous materials. Therefore, plastics and their derivatives are responsible for many air-borne and waterborne diseases in humans and animals.

Fossil fuels and crude oil that currently power the plastics recycling and resource recovery facilities are associated with the concerns of depleting resources, volatile prices and greenhouse gas emissions. These concerns relating to fossil fuels prompt seeking alternative sources of energy and materials that are renewable with a low carbon footprint. As mentioned earlier, conventional plastics are manufactured from fossil fuels such as petroleum and natural gas, whereas bioplastics are derived from plant and microbial biomasses. In contrast to conventional plastics produced from non-biodegradable polyolefin polymers, bioplastics are made from renewable biopolymers with chemi-mechanical properties analogous to conventional plastics with a feature of biodegradability. Bioplastics pose several positive impacts on the environment and economic aspects of polymer manufacturing on a global scale. Figure 2 makes a comparison of $\mathrm{CO}_{2}$ recycling in conventional and bioplastics. Bioplastics are among the biomaterials produced from waste plant biomass in addition to biofuels, biochemicals and other bioproducts (Gunarathne et al. 2019; Kaloudas et al. 2021; Pattnaik et al. 2021b; Patra et al. 2021).
There is adequate literature available on the conversion of plastics to clean fuels and chemicals. However, the literature is scarce on bioplastic polymers and their state-of-the-art applications. Intending to fill in the knowledge gaps, this article reviews some key building blocks of bioplastic polymers such as polyhydroxyalkanoate, polylactic acid, poly3-hydroxybutyrate, polyamide 11, polyhydroxyurethanes, as well as cellulose-based, starch-based, protein-based and lipid-based biopolymers (Fig. 3). The article also reviews the production statistics, market scenario, environmental and socioeconomic benefits of bioplastics. The chemistry, mechanical properties, production and applications of the above-mentioned bioplastic polymers are comprehensively discussed in this article.

\section{Bioplastics}

A polymeric material can be considered bioplastic if it is either bio-based or made from renewable materials with biodegradability potential (Mekonnen et al. 2013). Bioplastics are specific types of bioresource-based polymeric materials considered environmentally and economically viable to replace conventional petrochemical plastics. Many environmental problems relating to plastics can be eliminated by using biopolymers and bio-based fibers generated from bioresources and renewable wastes. Bio-based plastics are a significant innovation that can contribute to build up the bioeconomy and shift the dependency from fossil fuels to bioproducts.
Fig. 2 Environmental impacts of fossil fuel-based plastics and plant-based bioplastics. Note that conventional plastics emit a significant amount of $\mathrm{CO}_{2}$ and other toxic emissions from recycling processes. Apart from the compostable bioplastic polymers, the recycling of bioplastics is a process with low carbon emissions. Therefore, bioplastics can decrease greenhouse gas emissions by partially or fully eliminating the usage of fossil fuel derivatives with plant-based fibers and polymers

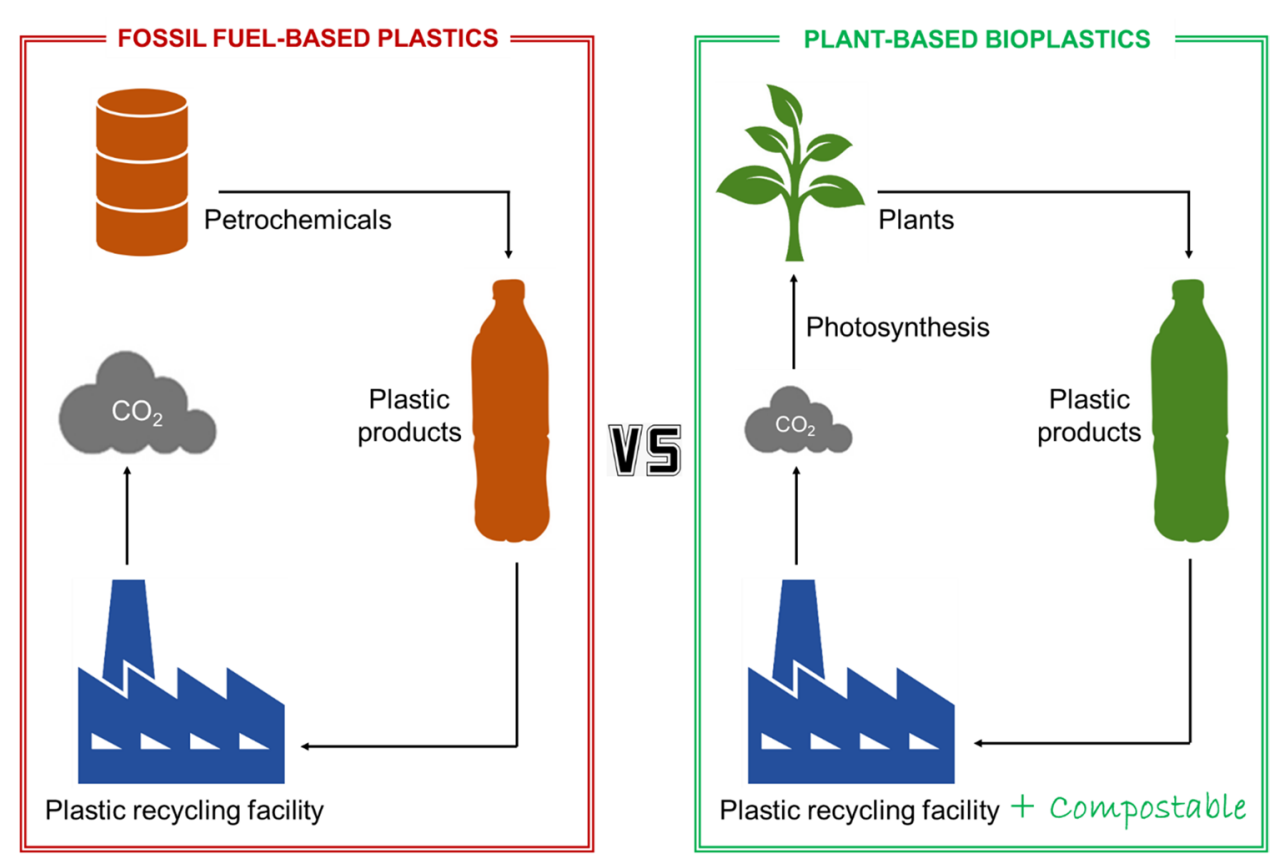




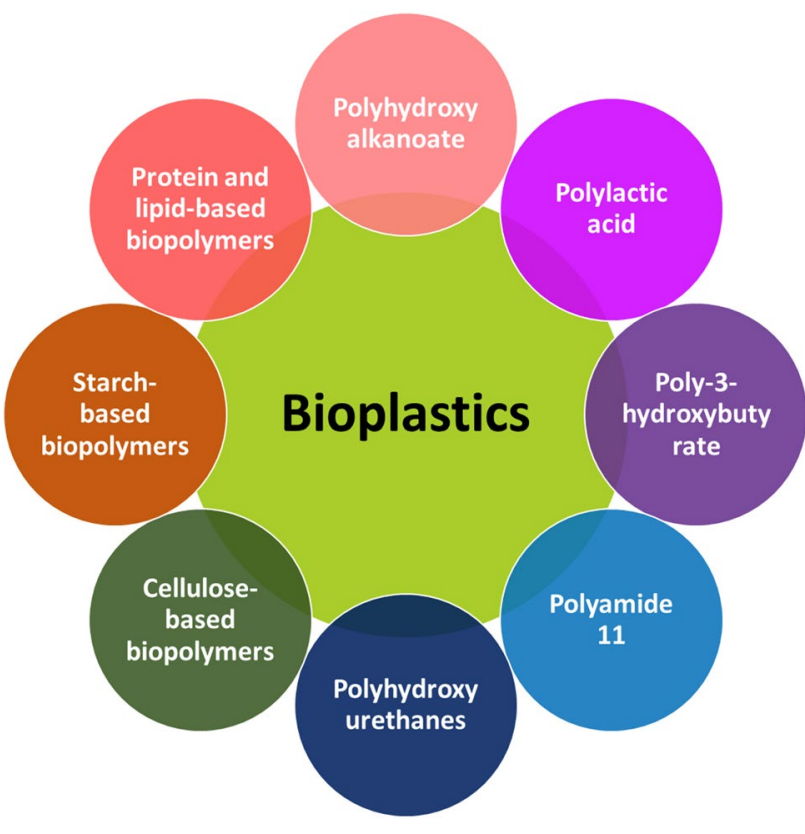

Fig. 3 Commonly used bioplastic polymers. Some most popular bioplastic polymers today are produced from polyhydroxyalkanoate, polylactic acid, poly-3-hydroxybutyrate, polyamide 11, polyhydroxyurethanes, cellulose, starch, proteins and lipids
Bio-based products are termed as industrial or commercial products (other than food or feed) composed partly or mostly of biological products (Mekonnen et al. 2013). Bio-based bioplastics are mainly made up of renewable resources through the activity of living organisms (Batori et al. 2018). As mentioned earlier, polyhydroxyalkanoate, polylactic acid, poly-3-hydroxybutyrate, polyamide 11, polyhydroxyurethanes, as well as cellulose-based, starch-based, protein-based and lipid-based biopolymers, are some promising biopolymers used in bioplastic industries.

Bioplastics are considered superior polymers compared to synthetic plastics due to their biocompatibility and biodegradability, which make them exceptional for applications in packaging, biomedical and other value-added industrial applications (Pathak et al. 2014; Prasanth et al. 2021). The major difference between conventional plastics and bioplastics is summarized in Table 1. Bioplastics usually take 3-6 months for complete biodegradation, whereas petrochemical-based plastics take several centuries to disintegrate. Based on environmental sustainability, a paradigm shift could be made from conventional plastics to bioplastics as illustrated in Fig. 4.

Table 1 Distinction between conventional plastics and bioplastics

\begin{tabular}{|c|c|}
\hline Conventional plastics & Bioplastics \\
\hline ommonly produced from fossil fuels and petrochemicals. & Produced from natural resources. \\
\hline Finite resources. & Renewable resources. \\
\hline Almost all plastics are non-biodegradable. & Most of the bioplastics are biodegradable. \\
\hline Takes centuries to disintegrate into smaller particles. & $\begin{array}{l}\text { Takes } 3-6 \text { months for complete biodegradation under controlled microbial compost- } \\
\text { ing conditions after the end-of-life use. }\end{array}$ \\
\hline Causes environmental pollution. & Environmentally friendly. \\
\hline $\begin{array}{l}\text { Used to manufacture packaging materials, grocery bags, } \\
\text { shoes, bottles, construction, textiles, electronic materi- } \\
\text { als, electrical cable, food packaging, etc. }\end{array}$ & $\begin{array}{l}\text { Used to manufacture biodegradable food packaging, compostable cutlery and coffee } \\
\text { pods, biocomposite automobile interior parts, edible films, carpets, bags, dispos- } \\
\text { able biomedical tools, bottles, etc. }\end{array}$ \\
\hline Emits high amount of greenhouse gases. & Emits fewer greenhouse gases. Considered carbon neutral. \\
\hline $\begin{array}{l}\text { Examples: High-density polyethylene, low-density poly- } \\
\text { ethylene, polyethylene terephthalate, polyvinyl chloride, } \\
\text { polystyrene and polypropylene. }\end{array}$ & $\begin{array}{l}\text { Examples: Polyhydroxyalkanoate, polylactic acid, poly-3-hydroxybutyrate, polyam- } \\
\text { ide 11, polyhydroxyurethanes as well as cellulose-based, starch-based, protein and } \\
\text { lipid-based biopolymers. }\end{array}$ \\
\hline
\end{tabular}

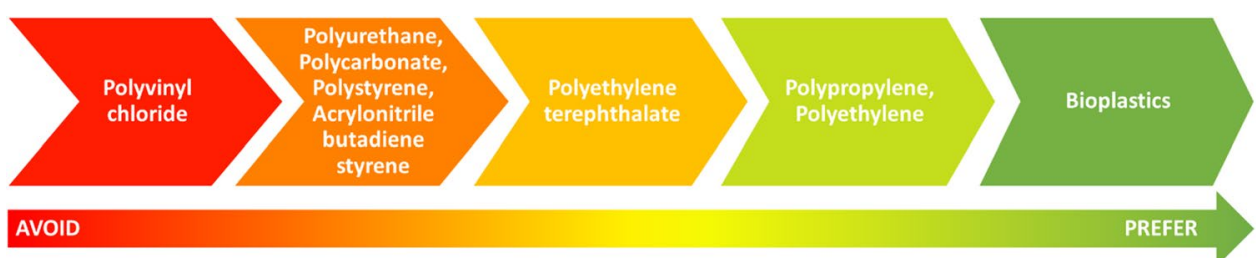

Fig. 4 Spectrum for the recommended usage of plastics considering environmental sustainability (Adapted from Arikan and Ozsoy 2015). Bioplastics are the most preferred followed by polypropylene, polyethylene and polyethylene terephthalate, polyurethane, polycarbonate, polystyrene and acrylonitrile butadiene styrene. Polyvinyl chloride is the least preferred among all plastics considering its contribution to environmental pollution 
The global market size for bioplastics is considered to burgeon every day with a projection to increase from the current USD \$9.2 billion to USD \$20 billion by 2026 (Grand View Research 2021; Intrado GlobeNewswire 2021a). The global production capacity of bioplastics in 2020 was over 2.1 million tonnes, which is projected to expand to 2.9 million tonnes by 2025 (European Bioplastics 2021). Asia remains the major production hub contributing to $46 \%$ of the total bioplastics produced globally followed by Europe, North America and South America that attribute to $26 \%$, $17 \%$ and $10 \%$ of the total production, respectively (European Bioplastics 2021).

The drop-in bio-based polyethylene, bio-based polyethylene terephthalate and bio-based polyamides currently contribute to 0.8 million tonnes or $40 \%$ of the global bioplastics production volumes (European Bioplastics 2021). Maximum usage of bioplastics in the present day is recognized in the packaging industry with consumption approaching 1 million tonnes or $47 \%$ of the total bioplastics produced. Out of the total worldwide agricultural land area of 4.8 billion hectares, only 0.7 million hectares of land area, or $0.015 \%$ of the global arable land, is used to grow feedstocks for use as precursors for bioplastics (European Bioplastics 2021). Therefore, it is also anticipated that bioplastics production from agricultural crop residues will not compete with the arable lands, pasture, food and fodder. The current applications of bioplastics in different industrial sectors are depicted in Fig. 5. Packaging industries stand out to be the most applied sector for bioplastics attributing to $47 \%$ or approximately 1 million tonnes of total bioplastics produced in 2020 .

Biodegradable bioplastics can be degraded by microorganisms under controlled environmental conditions without

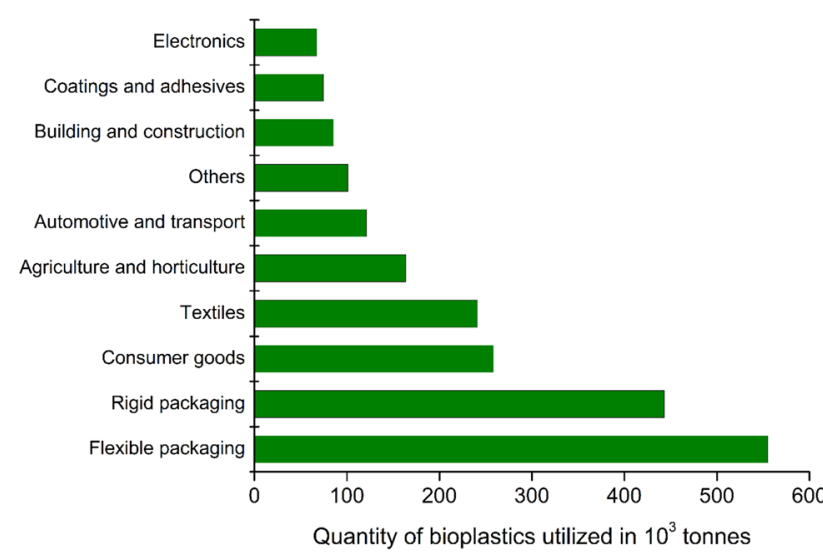

Fig. 5 Recent worldwide applications of bioplastics in different industrial sectors (Data source: European Bioplastics 2021). It is worth mentioning that bioplastics have found tremendous applications in packaging industries, consumer goods, textiles, agriculture, horticulture and automotive sectors. Currently, bioplastics are less applied in electronics, coatings, adhesives, building and construction sectors the release of any toxic byproducts (Arikan and Ozsoy 2015). Standard test methods established by the American Society for Testing and Materials (ASTM) and International Organization for Standardization (ISO) such as ASTM D5338-15 and ISO 14855-2:2018 are used to ascertain the rate and magnitude of ultimate aerobic biodegradation of plastic materials under controlled composting conditions at thermophilic temperatures and microbial activity (ASTM 2021; ISO 2018). The controlled environment requires specific thermophilic microorganisms under humid conditions to disintegrate bioplastics into $\mathrm{CO}_{2}$ and organic matter in the soil.

It should be noted that neither all bio-based plastics are biodegradable, nor all biodegradable plastics are bio-based. For example, polyethylene terephthalate can be produced from fossil fuel derivatives and bioresources. However, the bio-based polyethylene terephthalate can linger in the environment like its petrochemical counterpart without a controlled composting condition. On the contrary, plant-based polylactic acid is recyclable, biodegradable and compostable. The biodegradability mapping for bio-based and fossil fuel-based plastic resins is illustrated in Fig. 6. Bioplastics such as polylactic acid, polyhydroxyalkanoates, polybutylene succinate, as well as cellulose, starch, protein and lipids-based biopolymers, are not only bio-based but also biodegradable. In contrast, bio-based-polyethylene, biobased-polyethylene terephthalate, bio-based polyamide and bio-based-poly(trimethylene terephthalate) are bio-based but non-biodegradable. Although polybutylene adipate terephthalate and polycaprolactone are derived from fossil fuels, they are biodegradable. Last but not the least, plastics such as polyethylene, polypropylene, polyvinyl chloride, polyethylene terephthalate, high-density polyethylene and low-density polyethylene are derived from fossil fuels and deemed non-biodegradable. According to a report by the European Bioplastics (2021), the worldwide production of biodegradable plastics, although relatively greater than that of non-biodegradable plastics since 2019, is forecasted to continue in the coming years (Fig. 7).

\section{Bioplastic precursors}

\section{Polyhydroxyalkanoate}

Polyhydroxyalkanoate is an elastomeric or thermoplastic polyester of (R)-3-hydroxyalkanoic acids monomers that are synthesized biologically by various gram-positive and gram-negative bacteria as intracellular energy and carbon storage compounds (Keshavarz and Roy 2010). The pendant alkyl (-R) group can range from methyl group to tridecyl group as there are many hydroxyalkanoate units isolated with different $-\mathrm{R}$ groups (Mannina et al. 2020). This 


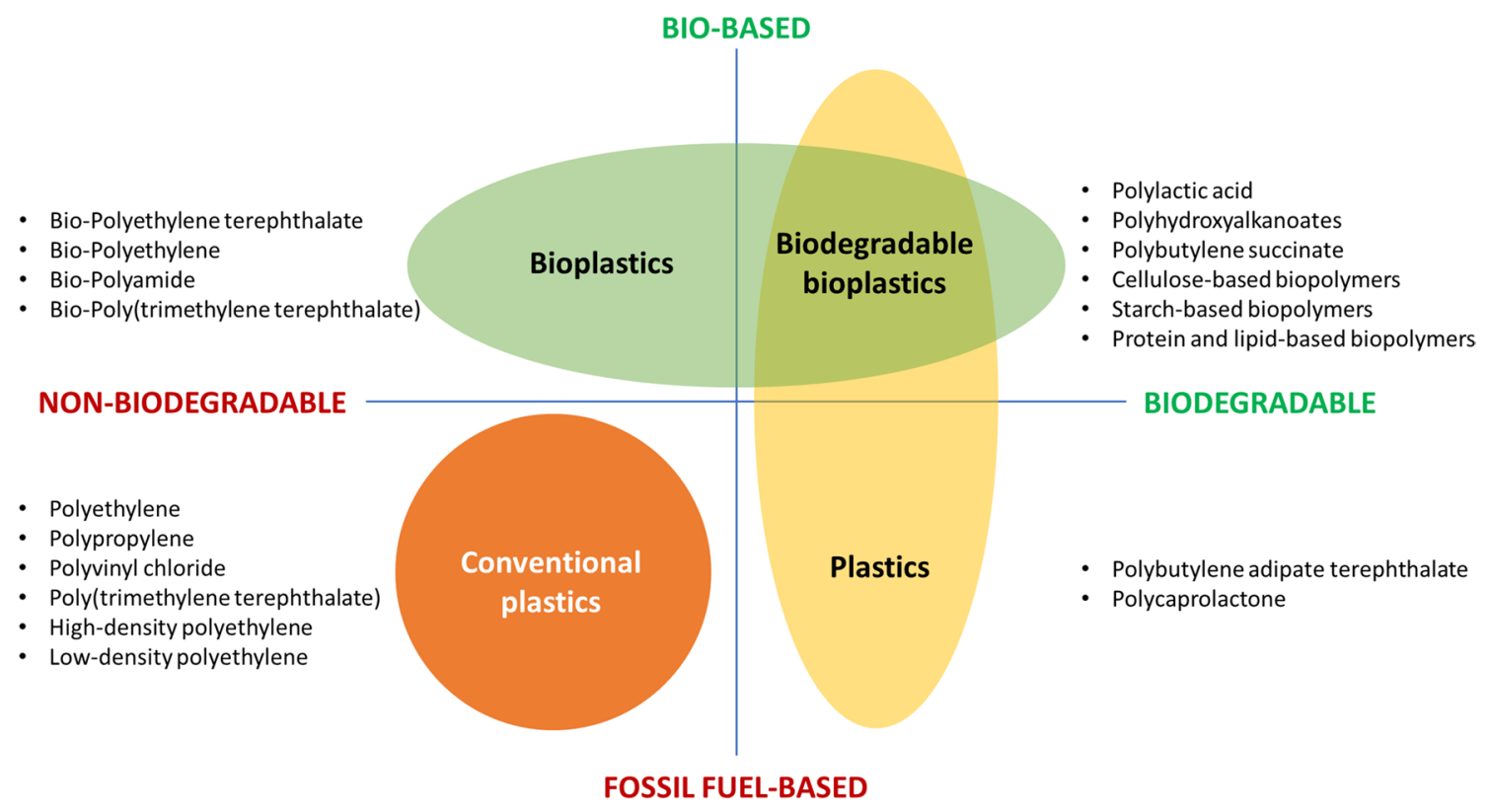

Fig. 6 Biodegradability mapping for plant-based and fossil fuel-based plastic resins. Bioplastics such as polylactic acid, polyhydroxyalkanoates, polybutylene succinate as well as cellulose, starch, protein and lipids-based biopolymers can be decomposed by microorganisms to $\mathrm{CO}_{2}$, water and compost under controlled conditions. are not only bio-based but also biodegradable. Petrochemically derived polybutylene adipate terephthalate and polycaprolactone are also considered

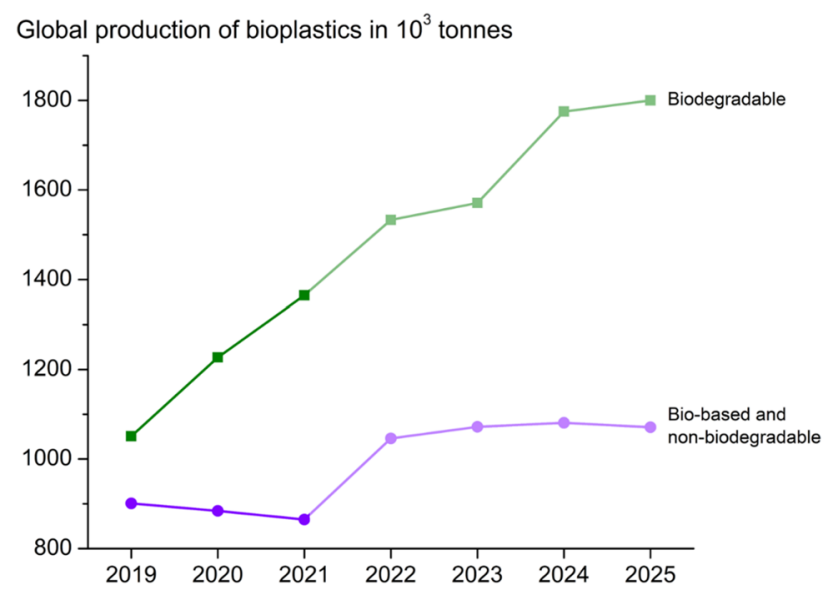

Fig. 7 Global production of bioplastics (Data source: European Bioplastics 2021). It is worth mentioning that the worldwide production of biodegradable bioplastics is projected to increase exponentially in the coming years, unlike bio-based non-biodegradable plastics that indicate a stationary growth pattern

class of polyesters is eco-friendly, biocompatible and biodegradable (Yu et al. 2020). A few notable applications of polyhydroxyalkanoate and its derivatives are highlighted in Table 2. Polyhydroxyalkanoate has received much attention for its vital use in medical and industrial fields (Choi et al. 2020). Polyhydroxyalkanoate has potential applications as biodegradable. On the other hand, polyethylene, polypropylene, polyvinyl chloride, poly(trimethylene terephthalate), high-density polypropylene and low-density polypropylene are petrochemically derived and non-biodegradable. Although polyethylene terephthalate, polypropylene, polyamide 11 and poly(trimethylene terephthalate) can be produced through bioresources, they cannot biodegrade naturally

biodegradable implants, drug carriers, tissue engineering, biocontrol agents, anticancer agents, antibacterial agents and memory enhancers (Ray and Kalia 2017). The global market for polyhydroxyalkanoate was USD \$62 million in 2020 with projections to approach USD $\$ 121$ million by 2025 at a compound annual growth rate of $14.2 \%$ (BusinessWire 2021).

Polyhydroxyalkanoates are produced by several microorganisms in the presence of carbon sources under the controlled amount of nitrogen, oxygen and phosphorous contents, as well as the optimal $\mathrm{pH}$ value of the growth medium (Chek et al. 2017; Kumar et al. 2020). Fermentation of lipids and sugars is performed by specific bacteria to produce linear polyesters like polyhydroxyalkanoate to store energy and carbon (Tarrahi et al. 2020). Different monomers can be attached to these polyesters to generate materials having desired and superior mechanical properties.

Polyhydroxyalkanoate polyesters are thermoplastic and can be synthesized by standard methods like the melting process. The characteristics of the polymer depend upon its chemical composition. These polymers are stable to ultraviolet radiation in contrast to other bioplastics such as polylactic acid (Tarrahi et al. 2020). Polyhydroxyalkanoates are soluble in halogenated solvents such as trichloromethane or chloroform, dichloroethane and dichloromethane (Silva et al. 2007). Large-scale production of polyhydroxyalkanoatecan 
Table 2 Biomedical applications of polyhydroxyalkanoate and derivatives

\begin{tabular}{|c|c|c|}
\hline Category & Potential applications & References \\
\hline Antibacterial & $\begin{array}{l}\text { (R)-3-hydroxyalkanoic acids can be produced by the degrada- } \\
\text { tion process of polyhydroxyalkanoate } \\
\text { (R)-3-hydroxyalkanoic acids can be used as a building block for } \\
\text { important compounds in pharmaceutical industries }\end{array}$ & Babel et al. (2001) \\
\hline Bio-controlling agent & $\begin{array}{l}\text { Polyhydroxyalkanoates are bio-polyesters of } \beta \text {-hydroxy short- } \\
\text { chain fatty acids, which can be metabolized in the intestinal } \\
\text { tract } \\
\text { These metabolites are advantageous as bio-controlling agents } \\
\text { for giant tiger prawn Penaeus monodon }\end{array}$ & Defoirdt et al. (2009); Ludevese-Pascual et al. (2016) \\
\hline Biodegradable implants & $\begin{array}{l}\text { Biopolymers such as polyhydroxyalkanoates have imparted } \\
\text { significant influence on modern medicines due to their biode- } \\
\text { gradable characteristics }\end{array}$ & Ulery et al. (2011) \\
\hline Biomedical devices & $\begin{array}{l}\text { Polyhydroxyalkanoates are used in manufacturing medical } \\
\text { devices due to their biocompatibility, biodegradability, and } \\
\text { mechanical strength } \\
\text { Polyhydroxyalkanoate is used in the meniscus repair device, } \\
\text { adhesion barriers, staples, screws, stents, repair patches, } \\
\text { rivets, etc. }\end{array}$ & $\begin{array}{l}\text { Lobler et al. (2002); Volova et al. (2003); Valappil } \\
\text { et al. (2006); Kenar et al. (2010) }\end{array}$ \\
\hline Drug carriers & $\begin{array}{l}\text { Polyhydroxyalkanoate can be used as a raw material for produc- } \\
\text { ing nanoparticles, tablets and as a scaffold for eluting drugs } \\
\text { that can be effective }\end{array}$ & Xiong et al. (2012); Nigmatullin et al. (2015) \\
\hline Tissue engineering & $\begin{array}{l}\text { Polyhydroxyalkanoates have the potential to develop scaffolds } \\
\text { of higher mechanical strength. Modified polyhydroxyal- } \\
\text { kanoates contribute to tissue engineering by developing tissue } \\
\text { products that hold vast medical and therapeutic applications }\end{array}$ & Ray and Kalia (2017) \\
\hline
\end{tabular}

is achieved by using inexpensive carbon sources such as cellulosic substrates, activated sludge and wastewater (Kaur and Roy 2015; Rodriguez-Perez et al. 2018). The mechanical properties of polyhydroxyalkanoates can be changed by altering their surface by other polymers, enzymes and inorganic materials (Tarrahi et al. 2020). The usage of polyhydroxyalkanoate as a biodegradable polyester has drawn much attention because of its biological properties and non-toxic behavior compared to conventional petrochemical polymers, which can be harmful to humans and the environment (Ray and Kalia 2017; Koller et al. 2017).

\section{Polylactic acid}

Polylactic acid is a thermoplastic polymer made up of renewable resources, unlike other synthetic polymers. Lactides or lactic acid monomers are the building blocks, which further polymerized to produce polylactic acid. Polylactic acid has gained much attention and application due to its mechanical characteristics when compared to conventional synthetic polymers such as polyethylene terephthalate and polystyrene (Karamanlioglu et al. 2017). Moreover, polylactic acid has many desirable properties such as easy fabrication, biocompatibility, biodegradability, superior mechanical strength, non-toxicity and better thermal plasticity (Karamanlioglu et al. 2017).
Upon biodegradation, polylactic acid releases $\mathrm{CO}_{2}$, water and decomposed organic matter, which further can be utilized by the green plants, thus imparting less carbon footprint. Additionally, polylactic acid does not release toxic intermediates and byproducts upon oxygenation. Polylactic acid has a relatively lower greenhouse gas emission rate when compared to other synthetic polymers. While one tonne of polylactic acid releases nearly $1600 \mathrm{~kg} \mathrm{CO}_{2}$, polyethylene terephthalate, polypropylene and polyamide 11 emit approximately 4140, 2740 and $7150 \mathrm{~kg} \mathrm{CO}_{2}$ per tonne, respectively (Karamanlioglu et al. 2017). Hence, it can be deduced that the production of polylactic acid is a closedloop system with a low carbon footprint. Furthermore, the production of polylactic acid from renewable agricultural materials has many advantages such as (Jamshidian et al. 2010):

(i) Less energy-intensive

(ii) Lower carbon footprint

(iii) Polylactic acid can be recycled back to lactic acid through alcoholysis or hydrolysis

(iv) Lactide monomers can be produced from lactic acid

(v) Potential to serve as a good packaging material that is biodegradable

(vi) Reduce the burden on landfills 
(vii) $\mathrm{CO}_{2}$ released upon the biodegradation of polylactic acid is utilization by green plants during photosynthesis

(viii) Improves agriculture-based economy

(ix) Desired product characteristics can be achieved by material modification

Polylactic acid is widely applied in green packaging polymer for fresh food products. It is also used in other sectors such as building, agriculture, transportation, furniture, electronic appliances, household products, fabrics and fibers. Polylactic acid has extraordinary characteristics in the packaging part due to its low production cost, renewable precursors, stiffness, mechanical strength, flexibility, twist and dead-fold retention, thermal stability, lower temperature heat sealing ability, as well as aroma and flavor resistance (Jamshidian et al. 2010).

The global polylactic acid market value is estimated to reach USD $\$ 5.9$ billion by 2027 (Intrado GlobeNewswire 2021c). The esthetic demands for polylactic acid are predominantly propelled by three-dimensional printing, food packaging, transport, agriculture and textile industries. The recent advancements in polylactic acid research have been focused on the augmentation of its inferior thermal and mechanical properties through stereo-complexed polylactides (Neo-polylactic acid or Neo-PLA). The stereocomplex form of polylactic acid comprises poly(L-lactide) and its enantiomer poly(D-lactide), which showcase a high melting temperature of $230{ }^{\circ} \mathrm{C}$ (Tutoni and Becker 2020). Furthermore, the composites of polylactic acid are gaining consideration because of their multipurpose properties and applications. The composites are reinforced with natural fibers to enhance their mechanical strength, making them ecofriendly and more affordable (Sanivada et al. 2020).

\section{Poly-3-hydroxybutyrate}

Poly-3-hydroxybutyrate, a polymer belonging to the polyhydroxyalkanoate family, is known for its biodegradability and biocompatibility. Poly-3-hydroxybutyrate is obtained microbially from the fermentation of renewable carbohydrate precursors (Mlalila et al. 2018). The synthesis pathway involves the condensation of acetoacetyl-Coenzyme A with $\beta$-ketothiolase catalyst, which generates acetoacetyl-CoA. It is further transformed to 3-hydroxybutyryl-CoA upon reduction. Finally, poly-3-hydroxybutyrate synthase catalyzes the 3-hydroxybutyryl-CoA to produce poly-3-hydroxybutyrate (Sirohi et al. 2021a,b).

Poly-3-hydroxybutyrate has remarkable characteristics such as high melting temperature $\left(177^{\circ} \mathrm{C}\right)$, tensile strength $(43 \mathrm{MPa})$, high resistance to ultraviolet radiation, glass transition temperature $\left(2{ }^{\circ} \mathrm{C}\right)$ and crystallinity $(60 \%)$, which are quite identical to the properties of some commonly used polyolefins such as polyethylene terephthalate, high-density polyethylene, low-density polyethylene and polypropylene (Sirohi et al. 2021a,b). Poly-3-hydroxybutyrate finds major applications in the biomedical industry for surgical implants, manufacturing of cardiac valves and dressings. In addition, the pharmacological application involves the encapsulation of medicines, whereas, in agricultural application, it is also used for the encapsulation of fertilizers. Poly-3-hydroxybutyrate is also popular in the packaging of food products and encapsulation of food supplements. Furthermore, other uses of Poly-3-hydroxybutyrate involve the manufacturing of disposable items, diapers and bottles (dos Santos et al. 2017).

Besides such benefits, the high production cost of poly3-hydroxybutyrate has induced its low production around the globe. The current global market price of poly-3-hydroxybutyrate, USD \$11,424 per tonne, is much higher compared to other plastics such as bio-based polylactic acid and fossilbased polyethylene terephthalate that sell for approximately USD \$2600 per tonne and USD \$1000 per tonne, respectively (Nieder-Heitmann et al. 2019). Recent research suggests the utilization of waste biomass as a carbon source for the economic production of poly-3-hydroxybutyrate (Nieder-Heitmann et al. 2019). Moreover, research efforts on exploring various bacterial cultures to enhance the productivity of poly-3-hydroxybutyrate are also underway (Sirohi et al. 2021a,b).

Poly-3-hydroxybutyrate films incorporated with different antimicrobial agents are highly capable of restricting microbial growth. In several studies, the incorporation of antimicrobial agents has been observed to enhance the effectiveness of the poly-3-hydroxybutyrate films (Mlalila et al. 2018). Xavier et al. (2015) studied the effectiveness of vanillin incorporated poly-3-hydroxybutyrate films against fungus such as Aspergillus fumigatus, Aspergillus niger, Aspergillus ochraceus and Penicillium viridicatum as well as bacteria such as Escherichia coli, Salmonella typhimurium and Staphylococcus aureus. Vanillin showed better efficacy against fungi compared to bacteria. In another study, Garrido-Miranda et al. (2018) studied the antioxidant and antifungal efficacy of poly-3-hydroxybutyrate incorporated with eugenol. Poly-3-hydroxybutyrate with 2.5 and 3 wt $\%$ of eugenol showed promising 2,2-diphenyl-1-picrylhydrazyl radical scavenging activity of $92 \%$ along with antifungal activity against Botrytis cinerea. The eugenol-incorporated poly-3-hydroxybutyrate with antioxidant and antifungal characteristics was found to be an encouraging biocomposite film for use in food packaging industries.

The syntheses routes of poly-3-hydroxybutyrate from marine prokaryotes, actinomycetes, algae, archaea and bacteria have immense commercial importance. Marine microbial species contain intracellular poly- $\beta$-hydroxybutyrate in the form of carbon and energy reserves under acute stress conditions. The marine species demonstrates tremendous 
survival ability and can diminish the damage from cellular freezing and dehydration. The marine microbially derived poly-3-hydroxybutyrate is gaining much attention owing to its advantages of lower expenses related to fermentation and product recovery. Furthermore, the presence of high salt concentrations reduces the possible contamination by other microorganisms.

\section{Polyamide 11 or nylon 11}

Polyamide 11 or nylon 11 is a bio-based polymer that belongs to the nylon family and is obtained by the polymerization of 11-aminoundecanoic acid. It is mainly produced from a bio-based renewable resource like castor oil and possesses high chemical and mechanical stability, making it highly attractive from an industrial and environmental perspective (Dechet et al. 2019). Polyamide 11 with a high melting temperature of $200^{\circ} \mathrm{C}$ is considered an effective reinforcement material for natural fibers as compared to other polyamides (Oliver-Ortega 2019).

Polyamide 11 is non-biodegradable and can be recycled along with its composites. Furthermore, its non-biodegradability property makes it effective for applications in manufacturing products with higher longevity. It finds application in the manufacturing of natural gas piping, water tubing, electrical cables, clips and wires. Nylon is also used as a fabric in textile industries and as bristles in the toothbrush. Furthermore, it is also used in aerospace and automobile industries, metal coatings, footwear, badminton racket strings and shuttlecocks (Martino et al. 2014; Nanni and Messori 2020).

Recent studies have shown that polyamide 11 reinforced with lignocellulosic fibers resembles mechanical properties equivalent to glass fiber reinforced polypropylene composites (Zierdt et al. 2015; Bourmaud et al. 2016; Oliver-Ortega et al. 2019). Biopolymers and wood fiber-based woodplastic composites significantly reduce carbon footprint and are more durable. Wood-plastic composites are known for their wide use in construction materials and longevity (Zeirdt et al. 2015). Polyamide 11 has greater potential in the generation of bio-based wood-plastic composites. Zierdt et al. (2015) studied bio-wood-plastic composites produced using polyamide 11 and beech fibers and observed enhanced mechanical and thermal properties of the product with high elastic and storage modulus. Polyamide 11 reinforced with lignocellulosic fibers also possesses high mechanical and thermal properties, which enables its use in manufacturing car interior parts and door handles. However, polyamide 11 composites have high energy consumption equivalent to polypropylene-based composites, which can be limited by using high natural fiber content-based-polyamide 11 composites (Oliver-Ortega et al. 2019). The comparison of strength and limitations associated with polyamide 11 is summarized in Table 3.

The recent advancements in research and development on polyamide 11 are focused on multi-jet fusion technology, which has enabled the fabrication of functional and convoluted polymeric parts. Multi-jet fusion is a development in polymeric powder bed fusion additive production methods (Tey et al. 2021). The polyamide 11 polymer powder is used for deposition in the multi-jet fusion fabrication process and sintering of powder occurs when exposed to infrared radiation (Lee et al. 2020). Polyamide 11 is receiving immense attention in recent years owing to its high ductility property and lower environmental impacts. The multi-jet fusion fabricated polyamide 11 parts are being utilized in the creation of surgically oriented prototypes, especially knee joints, femur bone, spinal cord and mandibular, as well as in threedimensional printing of prosthetic teeth (Arun et al. 2021). The global polyamide market value was USD \$27 billion in 2018, which is expected to reach USD $\$ 38$ billion by 2026 with a compound annual growth rate of $4.3 \%$ (Intrado GlobeNewswire 2021b).

\section{Polyhydroxyurethanes}

Polyhydroxyurethanes are a polymer obtained from the reaction between cyclic carbonates and amines. It is considered a prominent alternative to polyurethanes. The global market share for polyurethanes, estimated to be only $5 \%$, is associated with environmental pollution resulting from the use of isocyanate during production (Leitsch et al. 2016; Cornille et al. 2017). Therefore, polyhydroxyurethanes are getting much attention and have become a potential area of research. The synthesis of polyhydroxyurethanes includes various routes as follows: (i) co-polymerization of aziridine with $\mathrm{CO}_{2}$, (ii) polyaddition between a bicyclic carbonate and a

Table 3 Comparison of strength and limitations for polyamide 11

\begin{tabular}{ll}
\hline Strengths & Limitations \\
\hline Good resistance to oil and water & The market price is relatively higher compared to other polyamides \\
Higher melting temperature of $200{ }^{\circ} \mathrm{C}$ & Lower heat resistance and rigidity \\
Possesses higher resistance to ionization radiation & Lower resistance to ultraviolet radiation \\
Strong resistance to different chemicals, fuels and salt solutions & Weaker resistance to acetic acid and phenols \\
Resistant to abrasion, cracking and possesses greater longevity & Electrical properties are highly dependent on the moisture content
\end{tabular}


diamine, and (iii) trans-urethinization between bicarbamate and a diol (Aissa et al. 2016).

The environmental impact associated with the usage of isocyanate during the synthesis of polyurethanes has shifted the focus toward polyhydroxyurethanes. Polyhydroxyurethanes have evolved as one of the few promising sustainable materials to produce urethanes by limiting the use of toxic isocyanates. In some recent studies, the use of $\mathrm{CO}_{2}$ in synthesizing polyhydroxyurethanes has emerged as an effective way to reduce isocyanate dependency and eliminate 120 million tonnes per year of $\mathrm{CO}_{2}$ emissions (Nair et al. 2019). However, polyhydroxyurethane is associated with some limitations related to reaction parameters that can be overcome by using hybrid polyhydroxyurethanes. The hybrid polyhydroxyurethanes can be produced from the co-polymerization of polyhydroxyurethanes with different polymers. Some researchers have studied the use of epoxies or acrylates along with amines and cyclic carbonates to produce hybrid non-isocyanate polyurethane polymers (Suryawanshi et al. 2019; Ecochard and Caillol 2020).

The common mechanisms involved in the synthesis of non-isocyanate polyurethane are cyclic carbonate or polyaddition pathway, ring-opening polymerization, transurethanization and rearrangement (Suryawanshi et al. 2019). However, the replacement of isocyanate is sourced from petroleum-based products. Hence, it is not considered a sustainable way for the synthesis of non-isocyanate polyurethane polymers. On the other hand, vegetable oils can be an effective alternative to petroleum-based products (Miao et al. 2014). The use of linseed oil, castor oil and cashew nut shell oil has been studied for the synthesis of non-isocyanate polyurethanes. Furthermore, to improve the hardness and firmness, polyols could be blended with organic fillers such as cellulose (Suryawanshi et al. 2019).

Polyhydroxyurethanes consist of the high-density hydroxyl group, which enhances its mechanical properties making it appropriate for adhesive applications (Cornille et al. 2017). Along with the adhesion properties, polyhydroxyurethanes with acrylates and methacrylates can be used for coating applications. Polyhydroxyurethane possesses high thermal stability like polyurethanes, which finds application in thermosetting and thermoplastics. Furthermore, its rigid and flexible properties make it suitable for manufacturing foams, latex or hydrogels (Ecochard and Caillol 2020).

\section{Cellulose-based biopolymers}

Cellulose is a polysaccharide comprising monomers of glucose linked by stronger $\beta-1,4$ glycosidic linkages (Nanda et al. 2013). Cellulose is one of the predominant natural biopolymers found in lignocellulosic biomass of agricultural and forestry origin (Nanda et al. 2014).
Cellulose-based biopolymers are gaining much attention because of their biodegradability, high durability, strength and stiffness (Okolie et al. 2021b; Amorim et al. 2020; Qasim et al. 2021). The cellulose-based reinforced composites possess a low density, low price and non-abrasive nature (Polman et al. 2021). The distant tenuous molecules present in cellulose-based bioplastics consist of a weak hydrogen bond, which induces fast degradation. However, weaker hydrogen bonds diminish the mechanical properties like strength and flexibility of the cellulosebased bioplastics. Research suggests the blending cellulose with other polysaccharides such as pectin and chitosan can enhance stability, flexibility and transparency (Yaradoddi et al. 2020). Furthermore, cellulose is water sensitive and lacks interfacial adhesion and thermal stability, making cellulose-based composites less popular. However, pretreatments and chemical functionalization of cellulose can overcome such technical challenges (Polman et al. 2021).

Recent research studies have shown the use of cellulose as a bio-based filler material in the production of polymers, which enhances its biodegradability. Aguilar et al. (2019) studied cotton and sugarcane baggage-derived cellulose in producing magnetic bioplastics. In their study, biopolymers were immersed in a ferrofluid to produce magnetic bioplastic for use in optical and magnetic applications. In another study, cellulose from oil palm empty fruit bunch was used for the synthesis of biodegradable bioplastics where $\mathrm{CO}_{2}$ was the end product after degradation (Isroi and Cifriadi 2018). Hossain et al. (2018) used corn leaf-derived nanocellulose from developing a nanocoating material. Such edible bio-coating can be applied in coating drugs and capsules. Azmin and Nor (2020) have developed cellulose-based bioplastic film using cocoa pod husk and sugarcane baggage. The authors used agricultural wastes to produce high moisture-resistant food packaging films using a combination of $25 \%$ fiber and $75 \%$ cellulose. In another study, Yaradoddi et al. (2020) utilized agricultural waste-derived carboxymethyl cellulose-based material for developing packaging films.

Cellulose-based bioplastics including cellulose acetate are commonly used as packaging films, eyeglasses frames, food packaging and several other specialty materials. The cellulose-based bioplastic market is thriving because of its demand in manufacturing electronic items such as transparent dialers and screen shields as well as wearable electronics, headphones, cosmetic cases and automotive interior parts. Furthermore, cellulose and its derivatives can be used for pharmaceuticals, biomedical applications and three-dimensional printing (Plastemart 2021; Yaradoddi et al. 2020). Lignin, a phenylpropane polymer occurring naturally in lignocellulosic biomass, can also used as a precursor for bioplastics production (Spiridon 2020). 


\section{Starch-based biopolymers}

Starch-based biopolymers are gaining attention because of their renewability, biodegradability, abundance availability and inexpensiveness. Considered a most promising biopolymer for producing edible films, the affordability of starch makes it more appealing. Starch-based bioplastics compared to conventional plastics resemble identical mechanical properties and transparency (Shahabi-Ghahfarrokhi et al. 2019). Most plants produce polysaccharides for energy storage purposes. The major sources of starch are mostly food crops such as corn, cassava, wheat, rice and potatoes. Total $80 \%$ of the global starch production is from corn (Diyana et al. 2021). Therefore, the usage of food crops for extracting starch for large-scale production of biofuels, biochemicals and biomaterials raises concerns of competition to food crops and arable lands (Nanda et al. 2015).

The odor associated with the starch-based packaging film has adverse impacts on the packaged food items. Food packaging is a critical progression where raw material undergoes several extreme conditions such as high temperatures, extrusion and pressure. Such extreme conditions could result in the formation of various odorant compounds. The presence of amino acids and fatty acids in biopolymer worsens the rate of degradation (Khlestkin et al. 2018; Osorio et al. 2019). Therefore, it is highly essential to analyze the odorant compounds as the organoleptic properties of food products could be adversely altered. Osorio et al. (2019) conducted a study to detect vital odorant compounds present in starchderived polymers and characterize their aromatic profiles. The authors found trimethylamine, 2-nonenal, eugenol, and vinyl amyl ketone mostly responsible for the aroma in starchderived food packaging films.

In recent times, starch-based biopolymer films are widely incorporated with plant-derived essential oils to enhance their antimicrobial properties. Essential oils derived from cinnamon, peppermint, orange, lemon, clove and ginger are widely used in biopolymers owing to their effective antimicrobial and antibacterial activities (Table 4). Essential oils are highly effective in retarding microbial activity on films, which enable their demand in pharmaceutical and cosmeceutical industries (Jamróz et al. 2018a,b; Helal et al. 2019). Souza et al. (2013) investigated the influence of essential oils of clove and cinnamon blended with cassava starch-based films to create an adequate packaging. The study showed that all the films comprising essential oils demonstrated incredible antimicrobial activity against Eurotium amstelodami, Penicillium commune and other fungi commonly found in bakery products. In another study, Utami et al. (2019) used cinnamon-based essential oil for preparing tapioca films. The study showed that the tensile strength of the film gradually deteriorated with the increasing concentration of the essential oil. Gao et al. (2020) found a tensile strength of 5.2 MPa of the film incorporated with $0.5 \%$ soybean oil.

Starch is sensitive to moisture, lacks mechanical properties, thermal stability and has other inadequate physical characteristics such as low melting temperature, fragile structure and high gas permeability (Abe et al. 2021). However, after being incorporated with plasticizers, fibers, biopolymers and essential plant oils, the mechanical and chemical properties of starch-based biopolymers can be improved (Syafiq et al. 2020). Furthermore, to enhance the properties, advanced research is being conducted to use nanotechnology-based reinforced materials and ultraviolet irradiations. After being reinforced with natural or synthetic polymers, starch-based bioplastics can find applications in food packaging, biomedical and pharmaceutical fields. Starch-based coatings on fresh produce like fruits and vegetables have become popular as the film protects the loss of flavor, moisture and retards the ripening process while adding to the appealing esthetics (Thakur et al. 2019).

\section{Protein and lipid-based biopolymers}

Bioplastics can be produced from different plant- and animalbased proteins such as wheat gluten, soy protein, whey protein, zein, casein, collagen and gelatin. Protein, a heteropolymer of amino acids, is coupled by peptide bonds, and protein-based films possess better mechanical properties than polysaccharides. The structure of the protein is fibrous or globular and is
Table 4 Antimicrobial properties of biopolymers incorporated with essential oils

\begin{tabular}{llll}
\hline Biopolymer film material & Properties & Source of essential oils & References \\
\hline Cassava starch & Antimicrobial & Cinnamon and clove & Souza et al. (2013) \\
Chitosan & Antifungal & Lemon & Perdones et al. (2016) \\
Corn starch & Antimicrobial & Soyabean oil & Gao et al. (2020) \\
Milk protein & Antimicrobial & Nigella sativa & Ghamari et al. (2021) \\
Millet starch & Antimicrobial & Clove & Al-Hashimi et al. (2020) \\
Poly-3-hydroxybutyrate & Antifungal & Vanillin & Xavier et al. (2015) \\
Poly-3-hydroxybutyrate & Antifungal & Eugenol & Garrido-Miranda et al. (2018) \\
Starch-Farcelleran-gelatin & Antimicrobial & Lavender & Jamróz et al. (2018b) \\
Zein & Antibacterial & Cinnamon and mustard & Yun et al. (2015) \\
\hline
\end{tabular}


arranged by hydrogen, covalent and ionic bonds (Mohamed et al. 2020). Proteins are commonly used for packaging materials owing to their abundance, biodegradability, nutritional value and better film development capability. Protein-based films demonstrate tremendous mechanical properties and barriers to gas and aroma properties when compared to lipids and polysaccharides (Calva-Estrada et al. 2019).

Protein-based biopolymers are widely used in edible films having better mechanical properties than polysaccharides (Mohamed et al. 2020). The synthetic elastomers incorporated with keratin protein enhance the resulting product's thermal stability, mechanical properties and flame resistance. Soy protein blended with latexes produces products with characteristics equivalent to carbon black-filled elastomers (Garrison et al. 2016).

Lipids, generally obtained from plants, animals and insects, consist of fatty acids, glycerides, terpenes, fatty alcohol and phospholipids. The application of lipids in edible films and coatings offers many advantages such as glossy appearance, moisture entrapping and low production cost (Mohamed et al. 2020). Biopolymeric films made from oils and fats possess transparency, elasticity and water resistance, which can be used for packaging fruits, vegetables and meat products (Rodrigues et al. 2016). Moreover, essential oils present in coatings and films provide enhancement in antimicrobial and antibacterial properties. Similarly, plant-derived resins provide glossiness and emulsion stability while extending the shelf life of packaged food products (Mohamed et al. 2020).

Lipids are hydrophobic substances that can retard the moisture movement within food owing to their non-polar nature. Therefore, the food industry has made advancements in adopting lipids in edible and coating films for preserving food products. The hydrophobic essential oils consist of terpenoids and aromatic compounds, which augment their antimicrobial properties. The use of essential oils in biopolymer production has been widely used in food industries. Similarly, the use of waxes as coating or edible films is widely used for the packaging of fruits and vegetables. Chiumarelli and Hubinger (2014) reported developing a wax-based film with enhanced thermal, mechanical and physical properties. The film consisted of cassava starch, stearic acid, carnauba wax and glycerol. Furthermore, the application of the resin in edible films is commendable. Resins, derived from plants and insects, exhibit rapid drying, glossiness, transparency and emulsion stability. It can enhance the shelf life of fresh produces by up to 12 days (Mohamed et al. 2020).

\section{Challenges}

Synthetic plastics are made up of approximately $4 \%$ of crude oil that the world uses each year (Arikan and Ozsoy 2015). Factors such as the increasing crude oil demand and fluctuating prices can adversely affect synthetic plastic production. Moreover, the production of bioplastics uses less energy input than synthetic plastics. The fossil fuel-based energy required to produce bioplastics, $44 \mathrm{MJ} / \mathrm{kg}$ of bioresin, is much lower than that used to manufacture petrochemical-based plastics, which is $78-88 \mathrm{MJ} / \mathrm{kg}$ of resin ( $\mathrm{Yu}$ and Chen 2008).

Despite several advantages, several limitations and technical challenges are also associated with bioplastics. For example, the intermediate products generated during the synthesis of bioplastics can contaminate the recycling stream of conventional plastics if they are not separated at the source (Arikan and Ozsoy 2015). Additionally, most of the bioplastics produced today prefer first-generation feedstock such as sugarcane, corn, potato, wheat and cassava. It should be noted that the usage of first-generation feedstocks, especially starch-based materials for producing biofuels, biochemicals and biomaterials is severely criticized due to the competition to the food supply, arable lands, agricultural energy and cost investments (Okolie et al. 2019). To overcome this problem, inedible or lignocellulosic feedstocks, such as agricultural crop residues, woody biomass and invasive crops, should be explored for the extraction of natural polymers, fibers and resins (Prasanth et al. 2021; Pattnaik et al. 2021a; Okolie et al. 2021a).

Biodegradation of bioplastics is often questionable as certain polymers require controlled conditions for efficient biodegradation. Moreover, the bioplastics that contain a fraction of synthetic petrochemical-based polymer require additional steps for end-of-life remediation. In other words, the specific conditions required for the biodegradation of bioplastics such as temperature, $\mathrm{pH}$ and humidity cannot be necessarily achieved in landfills for near-complete composting of bioplastics. Therefore, direct landfilling of the biodegradable polymers might not be feasible. Moreover, installation of specific sites for the disposal of bioplastics requires land space, a controlled environment, regular monitoring, facilitated microbial proliferation, inoculation of specific polymer-degrading microorganisms along with their nutrient supply, routine mining of intermediates and byproducts as well as capital cost.

To make a paradigm shift, bioplastics must compete with the existing petrochemical-based conventional plastic manufactures in terms of low production cost, bulk manufacturing, compatibility with existing infrastructures, waste management, effective end-of-life remediation, consumer awareness, waste sorting at the consumer level and several other factors (Patel et al. 2021a,b). Nevertheless, the large-scale production of bioplastics can positively affect the global market and bioeconomy along with addressing several problems related to environmental pollution. Additionally, recent advancements in biotechnology and bioengineering can create huge opportunities 
to develop new bioplastics and engineered biopolymers that can be used for a wide variety of industries such as biomedical, automobile, veterinary, pharmaceuticals, agriculture and construction.

The long-term sustainability of bioplastics strongly depends on societal acceptance. Therefore, urban and rural communities worldwide need to be educated on the basics of bioplastics such as their usage, composition, environmental impacts, composting and waste sorting at the consumer or household levels. This can help shape the future bioplastic market and boost the agricultural economy to supply raw materials. Moreover, environmental problems can be mitigated by the enforcement of bylaws banning the usage of single-use plastics and urging the usage of bioplastics starting from commercial-level packaging to large-scale industrial applications.

\section{Conclusion}

Conventional synthetic polymers are considered hard-torecycle due to their highly heterogeneous nature, which creates environmental pollution. The numerous environmental impacts associated with plastic waste management techniques cannot be neglected. On the contrary, bioplastics are a feasible solution to reduce the reliance on conventional petrochemical-based synthetic plastics. Natural resources such as agricultural crop residues and woody biomasses can serve as precursors to recover the building blocks of bioplastics and biopolymers. Moreover, bioplastics are biocompatible, biodegradable and exhibit mechanical properties equivalent or superior to petrochemical-based plastics. Recent advancements in biotechnology and material engineering have positively impacted the production of biopolymers in unveiling their biodegradation characteristics.

Bioplastics seek more research and development in recycling techniques, large-scale production, cost, durability, sustainability, greenhouse gas emissions and optimum biodegradation. Inedible plant residues and microbial biomass and derivatives containing cellulose fibers and lignin biopolymer could be suitable alternatives for manufacturing bioplastics. Bioplastics are considered eco-friendly products in terms of sustainability and environmental risk assessment. Therefore, governmental support and social awareness are important to create a paradigm shift from petrochemical products to bio-based products.

Funding The authors would like to thank the Natural Sciences and Engineering Research Council of Canada (NSERC); Canada Research Chairs (CRC) program; Innovation, Science and Economic Development Canada as well as Next Generation Manufacturing Canada (NGen) for the financial support for this research.

\section{Declarations}

Conflict of interest None declared.

Consent for publication All authors agree to publish this article in Environmental Chemistry Letters.

\section{References}

Abe MM, Martins JR, Sanvezzo PB, Macedo JV, Branciforti MC, Halley P, Botaro VR, Brienzo M (2021) Advantages and disadvantages of bioplastics production from starch and lignocellulosic components. Polymers 13:2484. https://doi.org/10.3390/polym 13152484

Aguilar NM, Arteaga-Cardona F, de Anda Reyes ME, GervacioArciniega JJ, Salazar-Kuri U (2019) Magnetic bioplastics based on isolated cellulose from cotton and sugarcane bagasse. Mater Chem Phys 238:121921. https://doi.org/10.1016/j.matchemphys. 2019.121921

Aissa KA, Zheng JL, Estel L, Leveneur S (2016) Thermal stability of epoxidized and carbonated vegetable oils. Org Process Res Dev 20:948-953. https://doi.org/10.1021/acs.oprd.6b00040

Al-Hashimi AG, Ammar AB, Cacciola F, Lakhssassi N (2020) Development of a millet starch edible film containing clove essential oil. Foods 9:184. https://doi.org/10.3390/foods9020184

Arikan EB, Ozsoy HD (2015) A Review: Investigation of bioplastics. J Civil Eng Architect 9:188-192

Arun M, Sathishkumar N, Kumar KN, Ajai SS, Aswin S (2021) Development of patient-specific bio-polymer incisor teeth by $3 \mathrm{D}$ printing process: a case study. Mater Today Proc 39:1303-1308. https://doi.org/10.1016/j.matpr.2020.04.367

ASTM D5338-15(2021) (2021) Standard test method for determining aerobic biodegradation of plastic materials under controlled composting conditions, incorporating thermophilic temperatures. ASTM International, Pennsylvania, USA. DOI: https://doi.org/ 10.1520/D5338-15R21

Azmin SNHM, Nor MSM (2020) Development and characterization of food packaging bioplastic film from cocoa pod husk cellulose incorporated with sugarcane bagasse fibre. J Bioresour Bioprod 5:248-255. https://doi.org/10.1016/j.jobab.2020.10.003

Babel W, Ackermann JU, Breuer U (2001) Physiology, regulation, and limits of the synthesis of poly (3HB). In: Babel W, Steinbüchel A (eds) Biopolyesters. Springer, Berlin, Heidelberg, pp 125-157

Benson NU, Bassey DE, Palanisami T (2021) COVID pollution: impact of COVID-19 pandemic on global plastic waste footprint. Heliyon 7:e06343. https://doi.org/10.1016/j.heliyon.2021.e06343

Batori V, Akesson D, Zamani A, Taherzadeh MJ, Horvath IS (2018) Anaerobic degradation of bioplastics: a review. Waste Manag 80:406-413. https://doi.org/10.1016/j.wasman.2018.09.040

Bourmaud A, Le Duigou A, Gourier C, Baley C (2016) Influence of processing temperature on mechanical performance of unidirectional polyamide 11-flax fibre composites. Ind Crop Prod 84:151-165. https://doi.org/10.1016/j.indcrop.2016.02.007

BusinessWire (2021) Global Polyhydroxyalkanoate (PHA) Market (2020 to 2025) - Increasing Scope in End-use Segments Presents Opportunities - ResearchAndMarkets.com. https://www. businesswire.com/news/home/20210211005487/en/Global-Polyh ydroxyalkanoate-PHA-Market-2020-to-2025---IncreasingScope-in-End-use-Segments-Presents-Opportunities---Resea rchAndMarkets.com (accessed 10 August 2021)

Calva-Estrada SJ, Jiménez-Fernández M, Lugo-Cervantes E (2019) Protein-based films: Advances in the development 
of biomaterials applicable to food packaging. Food Eng Rev 11:78-92. https://doi.org/10.1007/s12393-019-09189-w

Chek MF, Kim SY, Mori T, Arsad H, Samian MR, Sudesh K, Hakoshima T (2017) Structure of polyhydroxyalkanoate (PHA) synthase PhaC from Chromobacterium sp. USM2, producing biodegradable plastics. Sci Rep 5:5312. https://doi.org/10. 1038/s41598-017-05509-4

Chia RW, Lee JY, Kim H, Jang J (2021) Microplastic pollution in soil and groundwater: a review. Environ Chem Lett 19:42114224. https://doi.org/10.1007/s10311-021-01297-6

Chiumarelli M, Hubinger MD (2014) Evaluation of edible films and coatings formulated with cassava starch, glycerol, carnauba wax and stearic acid. Food Hydrocoll 38:20-27. https://doi. org/10.1016/j.foodhyd.2013.11.013

Choi SY, Cho IJ, Lee Y, Kim YJ, Kim KJ, Lee SY (2020) Microbial polyhydroxyalkanoates and nonnatural polyesters. Adv Mater 32:1907138. https://doi.org/10.1002/adma.201907138

Cornille A, Blain M, Auvergne R, Andrioletti B, Boutevin B, Caillol S (2017) A study of cyclic carbonate aminolysis at room temperature: effect of cyclic carbonate structures and solvents on polyhydroxyurethane synthesis. Polym Chem 8:592-604. https://doi.org/10.1039/C6PY01854H

de Amorim JDP, de Souza KC, Duarte CR, da Silva DI, de Assis Sales Ribeiro F, Silva GS, de Farias PMA, Stingl A, Costa AFS, Vinhas GM, Sarubbo LA, (2020) Plant and bacterial nanocellulose: production, properties and applications in medicine, food, cosmetics, electronics and engineering. a review. Environ Chem Lett 18:851-869. https://doi.org/10.1007/ s10311-020-00989-9

Dechet MA, Goblirsch A, Romeis S, Zhao M, Lanyi FJ, Kaschta J, Schmidt J (2019) Production of polyamide 11 microparticles for Additive Manufacturing by liquid-liquid phase separation and precipitation. Chem Eng Sci 197:11-25. https://doi.org/10. 1016/j.ces.2018.11.051

Defoirdt T, Boon N, Sorgeloos P, Verstraete W, Bossier P (2009) Shortchain fatty acids and poly-b-hydroxyalkanoates: (New) biocontrol agents for a sustainable animal production. Biotechnol Adv 27:680-685. https://doi.org/10.1016/j.biotechadv.2009.04.026

Diyana ZN, Jumaidin R, Selamat MZ, Ghazali I, Julmohammad N, Huda N, Ilyas RA (2021) Physical properties of thermoplastic starch derived from natural resources and its blends: A review. Polymers 13:1396. https://doi.org/10.3390/polym13091396

dos Santos AJ, Valentina LVOD, Schulz AAH, Duarte MAT (2017) From obtaining to degradation of PHB: material properties. Part I. Ing Cienc 13:269-298

Ecochard Y, Caillol S (2020) Hybrid polyhydroxyurethanes: How to overcome limitations and reach cutting edge properties? Eur Polym J 137:109915. https://doi.org/10.1016/j.eurpolymj.2020. 109915

European Bioplastics (2021) Bioplastics market data. https://www. european-bioplastics.org/market/ (accessed on 2 August 2021)

Fawzy S, Osman AI, Doran J, Rooney DW (2020) Strategies for mitigation of climate change: a review. Environ Chem Lett 18:20692094. https://doi.org/10.1007/s10311-020-01059-w

Gao W, Wu W, Liu P, Hou H, Li X, Cui B (2020) Preparation and evaluation of hydrophobic biodegradable films made from corn/ octenylsuccinated starch incorporated with different concentrations of soybean oil. Int J Biol 142:376-383. https://doi.org/10. 1016/j.ijbiomac.2019.09.108

Garrido-Miranda KA, Rivas BL, Pérez-Rivera MA, Sanfuentes EA, Peña-Farfal C (2018) Antioxidant and antifungal effects of eugenol incorporated in bionanocomposites of poly(3hydroxybutyrate)-thermoplastic starch. LWT 98:260-267. https://doi.org/10.1016/j.lwt.2018.08.046
Garrison TF, Murawski A, Quirino RL (2016) Bio-based polymers with potential for biodegradability. Polymers 8:262. https://doi. org/10.3390/polym8070262

Ghamari MA, Amiri S, Rezazadeh-Bari M, Rezazad-Bari L (2021) Physical, mechanical, and antimicrobial properties of active edible film based on milk proteins incorporated with Nigella sativa essential oil. Polym Bull. https://doi.org/10.1007/ s00289-021-03550-y

Gorrasi G, Sorrentino A, Lichtfouse E (2021) Back to plastic pollution in COVID times. Environ Chem Lett 19:1-4. https://doi.org/10. 1007/s10311-020-01129-z

Grand View Research (2021) Bioplastics Market Size, Share \& Trends Analysis Report By Product (Biodegradable, Non-biodegradable), By Application (Packaging, Automotive \& Transportation, Textile), By Region, And Segment Forecasts, 2021 - 2028. https://www.grand viewresearch.com/industry-analysis/biopl astics-industry\#: :text=The $\% 20$ global\%20bioplastics\%20mar ket\%20size\%20was\%20estimated\%20at\%20USD\%208.3,USD\% $209.2 \%$ 20billion\%20in\%202020.\&text=The\%20global\%20bio plastics\%20market\%20is,USD\%2026.0\%20billion\%20by\% 202027. (accessed 2 August 2021)

Gunarathne V, Ashiq A, Ramanayaka S, Wijekoon P, Vithanage M (2019) Biochar from municipal solid waste for resource recovery and pollution remediation. Environ Chem Lett 17:1225-1235. https://doi.org/10.1007/s10311-019-00866-0

Helal IM, El-Bessoumy A, Al-Bataineh E, Joseph MR, Rajagopalan P, Chandramoorthy HC, Ahmed SBH (2019) Antimicrobial efficiency of essential oils from traditional medicinal plants of Asir region, Saudi Arabia, over drug resistant isolates. BioMed Res Int 2019:8928306. https://doi.org/10.1155/2019/8928306

Hossain AS, Uddin MM, Veettil VN, Fawzi M (2018) Nano-cellulose based nano-coating biomaterial dataset using corn leaf biomass: An innovative biodegradable plant biomaterial. Data Brief 17:162-168. https://doi.org/10.1016/j.dib.2017.12.046

Intrado GlobeNewswire (2021a) Bioplastics Market Size Expected to Reach USD 19.93 Billion by 2026 I Fortune Business Insights ${ }^{\mathrm{TM}}$. https://www.globenewswire.com/news-release/2021/03/30/ 2201786/0/en/Bioplastics-Market-Size-Expected-to-ReachUSD-19-93-Billion-by-2026-Fortune-Business-Insights.html (accessed 2 August 2021)

Intrado GlobeNewswire (2021b) Polyamide Market To Reach USD 38.30 Billion By 2026 I Reports And Data. https://www.globe newswire.com/news-release/2019/07/15/1882593/0/en/Polya mide-Market-To-Reach-USD-38-30-Billion-By-2026-ReportsAnd-Data.html (accessed 2 August 2021)

Intrado GlobeNewswire (2021c) Polylactic Acid Market Size to Reach USD 5,944.9 Million by 2027 I Growing Demand for Sustainable and Green Packaging are Key Factors Driving Industry Revenue Growth, says Emergen Research. https://www.globenewswire. com/en/news-release/2021/06/15/2246915/0/en/Polylactic-AcidMarket-Size-to-Reach-USD-5-944-9-Million-by-2027-GrowingDemand-for-Sustainable-and-Green-Packaging-are-Key-Facto rs-Driving-Industry-Revenue-Growth-says-Emergen-Res.html (accessed 2 August 2021)

ISO 14855-2:2018 (2018) Determination of the ultimate aerobic biodegradability of plastic materials under controlled composting conditions - Method by analysis of evolved carbon dioxide Part 2: Gravimetric measurement of carbon dioxide evolved in a laboratory-scale test. International Organization for Standardization. ISO Central Secretariat, Geneva, Switzerland.

Isroi I, Cifriadi A (2018) Oxidation of cellulose from oil palm empty fruit bunch using hydrogen peroxide in alkaline condition. J Selulosa 8:51-60

Jamróz E, Juszczak L, Kucharek M (2018a) Development of starchfurcellaran-gelatin films containing tea tree essential oil. J Appl 
Polym Sci 135:46754. https://doi.org/10.1016/j.ijbiomac.2018. 04.014

Jamróz E, Juszczak L, Kucharek M (2018b) Investigation of the physical properties, antioxidant and antimicrobial activity of ternary potato starch-furcellaran-gelatin films incorporated with lavender essential oil. Int J Biol 114:1094-1101. https://doi.org/10.1016/j. ijbiomac.2018.04.014

Jamshidian M, Tehrany EA, Imran M, Jacquot M, Desobry S (2010) Poly-lactic acid: production, applications, nanocomposites, and release studies. Comp Rev Food Sci Food Saf 9:552-571. https:// doi.org/10.1111/j.1541-4337.2010.00126.x

Kaloudas D, Pavlova N, Penchovsky R (2021) Lignocellulose, algal biomass, biofuels and biohydrogen: a review. Environ Chem Lett 19:2809-2824. https://doi.org/10.1007/s10311-021-01213-y

Karamanlioglu M, Preziosi R, Robson GD (2017) Abiotic and biotic environmental degradation of the bioplastic polymer poly(lactic acid): a review. Polym Degrad Stabil 137:122-130. https://doi. org/10.1016/j.polymdegradstab.2017.01.009

Kaur G, Roy I (2015) Strategies for large-scale production of polyhydroxyalkanoates. Chem Biochem Eng Quart 29:157-172

Kenar H, Kose GT, Hasirci V (2010) Design of a 3D aligned myocardial tissue construct from biodegradable polyesters. J Mater Sci Mater Med 21:989-997. https://doi.org/10.1007/ s10856-009-3917-8

Keshavarz T, Roy I (2010) Polyhydroxyalkanoates: bioplastics with a green agenda. Curr Opin Microbiol 13:321-326. https://doi.org/ 10.1016/j.mib.2010.02.006

Khlestkin VK, Peltek SE, Kolchanov NA (2018) Review of direct chemical and biochemical transformations of starch. Carbohydr Polym 181:460-476. https://doi.org/10.1016/j.carbpol.2017.10. 035

Koller M, Maršálek L, de Sousa Dias MM, Braunegg G (2017) Producing microbial polyhydroxyalkanoate (PHA) biopolyesters in a sustainable manner. New Biotechnol 37:24-38. https://doi.org/ 10.1016/j.nbt.2016.05.001

Kumar M, Rathour R, Singh R, Sun Y, Pandey A, Gnansounou E, Lin KYA, Tsang DCW, Thakur IS (2020) Bacterial polyhydroxyalkanoates: opportunities, challenges, and prospects. J Clean Prod 263:121500. https://doi.org/10.1016/j.jclepro.2020.121500

Kuswandi B (2017) Environmental friendly food nano-packaging. Environ Chem Lett 15:205-221. https://doi.org/10.1007/ s10311-017-0613-7

Lee KPM, Pandelidi C, Kajtaz M (2020) Build orientation effects on mechanical properties and porosity of polyamide- 11 fabricated via multi-jet fusion. Addit Manuf 36:101533. https://doi.org/10. 1016/j.addma.2020.101533

Leitsch EK, Heath WH, Torkelson JM (2016) Polyurethane/polyhydroxyurethane hybrid polymers and their applications as adhesive bonding agents. Int J Adhes Adhes 64:1-8. https://doi.org/10. 1016/j.ijadhadh.2015.09.001

Li WC, Tse HF, Fok L (2016) Plastic waste in the marine environment: a review of sources, occurrence and effects. Sci Total Environ 566-567:333-349. https://doi.org/10.1016/j.scitotenv.2016.05. 084

Lobler M, Sab M, Kunze C, Schmitz KP, Hopt UT (2002) Biomaterial implants induce the inflammation marker CRP at the site of implantation. J Biomed Mater Res 61:165-167. https://doi.org/ $10.1002 / j b m .10155$

Ludevese-Pascual G, Laranja JLQ, Amar EC, Sorgeloos P, Bossier P, De Schryver P (2016) Poly-beta-hydroxybutyrateenriched Artemia sp. for giant tiger prawn Penaeus monodon larviculture. Aquac Nutr 23:422-429. https://doi.org/10.1111/anu.12410

Mannina G, Presti D, Montiel-Jarillo G, Carrera J, Suárez-Ojeda ME (2020) Recovery of polyhydroxyalkanoates (PHAs) from wastewater: a review. Bioresour Technol 297:122478. https://doi.org/ 10.1016/j.biortech.2019.122478
Martino L, Basilissi L, Farina H, Ortenzi MA, Zini E, Di Silvestro G, Scandola M (2014) Bio-based polyamide 11: synthesis, rheology and solid-state properties of star structures. Eur Polym J 59:69-77. https://doi.org/10.1016/j.eurpolymj.2014.07.012

Mekonnen T, Mussone P, Khalil H, Bressler D (2013) Progress in biobased plastics and plasticizing modifications. J Mater Chem a 1:13379-13398. https://doi.org/10.1039/C3TA12555F

Miao S, Wang P, Su Z, Zhang S (2014) Vegetable-oil-based polymers as future polymeric biomaterials. Acta Biomater 10:1692-1704. https://doi.org/10.1016/j.actbio.2013.08.040

Mlalila N, Hilonga A, Swai H, Devlieghere F, Ragaert P (2018) Antimicrobial packaging based on starch, poly (3-hydroxybutyrate) and poly (lactic-co-glycolide) materials and application challenges. Trends Food Sci Technol 74:1-11. https://doi.org/10. 1016/j.tifs.2018.01.015

Mohamed SA, El-Sakhawy M, El-Sakhawy MAM (2020) Polysaccharides, protein and lipid-based natural edible films in food packaging: a review. Carbohydr Polym 238:116178. https://doi.org/10. 1016/j.carbpol.2020.116178

Mu X, Qi S, Liu J, Yuan L, Huang Y, Xue J, Qian L, Wang C, Li Y (2021) Toxicity and behavioral response of zebrafish exposed to combined microplastic and bisphenol analogues. Environ Chem Lett. https://doi.org/10.1007/s10311-021-01320-w

Nair AS, Cherian S, Balachandran N, Panicker UG, Sankaranarayanan SKK (2019) Hybrid poly(hydroxy urethane)s: Folded-sheet morphology and thermoreversible adhesion. ACS Omega 4:1304213051. https://doi.org/10.1021/acsomega.9b00789

Nanda S, Azargohar R, Dalai AK, Kozinski JA (2015) An assessment on the sustainability of lignocellulosic biomass for biorefining. Renew Sustain Energy Rev 50:925-941. https://doi.org/10. 1016/j.rser.2015.05.058

Nanda S, Berruti F (2021a) A technical review of bioenergy and resource recovery from municipal solid waste. J Hazard Mater 403:123970. https://doi.org/10.1016/j.jhazmat.2020.123970

Nanda S, Berruti F (2021b) Municipal solid waste management and landfilling technologies: a review. Environ Chem Lett 19:14331456. https://doi.org/10.1007/s10311-020-01100-y

Nanda S, Berruti F (2021c) Thermochemical conversion of plastic waste to fuels: a review. Environ Chem Lett 19:123-148. https:// doi.org/10.3390/ma14102586

Nanda S, Mohammad J, Reddy SN, Kozinski JA, Dalai AK (2014) Pathways of lignocellulosic biomass conversion to renewable fuels. Biomass Convers Bioref 4:157-191. https://doi.org/10. 1007/s13399-013-0097-z

Nanda S, Mohanty P, Pant KK, Naik S, Kozinski JA, Dalai AK (2013) Characterization of North American lignocellulosic biomass and biochars in terms of their candidacy for alternate renewable fuels. BioEnergy Res 6:663-677. https://doi.org/10.1007/ s12155-012-9281-4

Nanda S, Okolie JA, Patel R, Pattnaik F, Fang Z, Dalai AK, Kozinski JA, Naik S (2021) Catalytic hydrothermal co-gasification of canola meal and low-density polyethylene using mixed metal oxides for hydrogen production. Int J Hydrogen Energy. https:// doi.org/10.1016/j.ijhydene.2021.08.179

Nanda S, Reddy SN, Hunter HN, Vo DVN, Kozinski JA, Gökalp I (2019) Catalytic subcritical and supercritical water gasification as a resource recovery approach from waste tires for hydrogenrich syngas production. J Supercrit Fluids 154:104627. https:// doi.org/10.1016/j.supflu.2019.104627

Nanni A, Messori M (2020) Thermo-mechanical properties and creep modelling of wine lees filled polyamide 11 (PA11) and polybutylene succinate (PBS) bio-composites. Comp Sci Technol 188:107974. https://doi.org/10.1016/j.compscitech.2019.107974

Naqash N, Prakash S, Kapoor D, Singh R (2020) Interaction of freshwater microplastics with biota and heavy metals: a review. 
Environ Chem Lett 18:1813-1824. https://doi.org/10.1007/ s10311-020-01044-3

Nieder-Heitmann M, Haigh K, Görgens JF (2019) Process design and economic evaluation of integrated, multi-product biorefineries for the co-production of bio-energy, succinic acid, and polyhydroxybutyrate (PHB) from sugarcane bagasse and trash lignocelluloses. Biofuel Bioprod Biorefin 13:599-617. https://doi.org/ 10.1002/bbb. 1972

Nigmatullin R, Thomas P, Lukasiewicz B, Puthussary H, Roy I (2015) Polyhydroxyalkanoates, a family of natural polymers, and their applications in drug delivery. J Chem Technol Biotechnol 90:1209-1221. https://doi.org/10.1002/jctb.4685

Okolie JA, Mukherjee A, Nanda S, Dalai AK, Kozinski JA (2021a) Next-generation biofuels and platform biochemicals from lignocellulosic biomass. Int J Energy Res 45:14145-14169. https:// doi.org/10.1002/er.6697

Okolie JA, Nanda S, Dalai AK, Kozinski JA (2021b) Chemistry and specialty industrial applications of lignocellulosic biomass. Waste Biomass Valor 12:2145-2169. https://doi.org/10.1007/ s12649-020-01123-0

Okolie JA, Rana R, Nanda S, Dalai AK, Kozinski JA (2019) Supercritical water gasification of biomass: a state-of-the-art review of process parameters, reaction mechanisms and catalysis. Sustain Energy Fuels 3:578-598. https://doi.org/10.1039/c8se00565f

Oliver-Ortega H, Julian F, Espinach FX, Tarrés Q, Ardanuy M, Mutjé $P$ (2019) Research on the use of lignocellulosic fibers reinforced bio-polyamide 11 with composites for automotive parts: car door handle case study. J Clean Prod 226:64-73. https://doi.org/10. 1016/j.jclepro.2019.04.047

Osorio J, Aznar M, Nerín C (2019) Identification of key odorant compounds in starch-based polymers intended for food contact materials. Food Chem 285:39-45. https://doi.org/10.1016/j.foodchem. 2019.01.157

Othman AR, Hasan HA, Muhamad MH, Ismail NI, Abdullah SRS (2021) Microbial degradation of microplastics by enzymatic processes: a review. Environ Chem Lett 19:3057-3073. https://doi. org/10.1007/s10311-021-01197-9

Padervand M, Lichtfouse E, Robert D, Wang C (2020) Removal of microplastics from the environment. A review. Environ Chem Lett 18:807-828. https://doi.org/10.1007/s10311-020-00983-1

Patel R, Nanda S, Dalai AK (2021a) Conversion of municipal solid waste to biofuels. In: Nanda S, Vo DVN (eds) Progressive Thermochemical Biorefining Technologies. CRC Press, Florida, USA, pp 43-61

Patel R, Nanda S, Dalai AK (2021b) Conversion of plastic waste to fuels and chemicals. In: Nanda S, Vo DVN (eds) Progressive Thermochemical Biorefining Technologies. CRC Press, Florida, USA, pp 63-73

Pathak S, Sneha CLR, Mathew BB (2014) Bioplastics: its timeline based scenario \& challenges. J Polymer Biopolymer Phys Chem 2:84-90

Patra BR, Mukherjee A, Nanda S, Dalai AK (2021) Biochar production, activation and adsorptive applications: a review. Environ Chem Lett 19:2237-2259. https://doi.org/10.1007/s10311-020-01165-9

Pattnaik F, Nanda S, Kumar V, Naik S, Dalai AK (2021a) Subcritical water hydrolysis of Phragmites for sugar extraction and catalytic conversion to platform chemicals. Biomass Bioenergy 145:105965. https://doi.org/10.1016/j.biombioe.2021.105965

Pattnaik F, Tripathi S, Patra BR, Nanda S, Kumar V, Dalai AK, Naik S (2021b) Catalytic conversion of lignocellulosic polysaccharides to commodity biochemicals: a review. Environ Chem Lett 19:4119-4136. https://doi.org/10.1007/s10311-021-01284-x

Perdones Á, Escriche I, Chiralt A, Vargas M (2016) Effect of chitosanlemon essential oil coatings on volatile profile of strawberries during storage. Food Chem 197A:979-986. https://doi.org/10. 1016/j.foodchem.2015.11.054

Plastemart (2021) Cellulose-based plastics address need for more sustainable raw materials from food, healthcare, coatings and construction. http://www.plastemart.com/plastic-technical-artic les/cellulose-based-plastics-address-need-for-more-sustainableraw-materials-from-food-healthcare-coatings-and-construction/ 2356 (accessed 2 August 2021)

Polman EM, Gruter GJM, Parsons JR, Tietema A (2021) Comparison of the aerobic biodegradation of biopolymers and the corresponding bioplastics: a review. Sci Total Environ 753:141953. https://doi.org/10.1016/j.scitotenv.2020.141953

Prasanth SM, Kumar PS, Harish S, Rishikesh M, Nanda S, Vo DVN (2021) Application of biomass derived products in mid-size automotive industries: a review. Chemosphere 280:130723. https:// doi.org/10.1016/j.chemosphere.2021.130723

Qasim U, Osman AI, Al-Muhtaseb AH, Farrell C, Al-Abri M, Ali M, Vo D-VN, Jamil F, Rooney DW (2021) Renewable cellulosic nanocomposites for food packaging to avoid fossil fuel plastic pollution: a review. Environ Chem Lett 19:613-641. https://doi. org/10.1007/s10311-020-01090-x

Ray S, Kalia VC (2017) Biomedical applications of polyhydroxyalkanoates. Indian J Microbiol 57:261-269. https://doi.org/10. 1007/s12088-017-0651-7

Rodrigues DC, Cunha AP, Brito ES, Azeredo HM, Gallão MI (2016) Mesquite seed gum and palm fruit oil emulsion edible films: Influence of oil content and sonication. Food Hydrocoll 56:227235. https://doi.org/10.1016/j.foodhyd.2015.12.018

Rodriguez-Perez S, Serrano A, Pantion AA, Alonso-Farinas B (2018) Challenges of scaling-up PHA production from waste streams. A review. J Environ Manag 205:215-230. https://doi.org/10.1016/j. jenvman.2017.09.083

Razeghi N, Hamidian AH, Wu C, Zhang Y, Yang M (2021) Microplastic sampling techniques in freshwaters and sediments: a review. Environ Chem Lett 19:4225-4252. https://doi.org/10.1007/ s10311-021-01227-6

Rustagi N, Pradhan SK, Singh R (2011) Public health impact of plastics: an overview. Indian J Occup Environ Med 15:100-103. https://doi.org/10.4103/0019-5278.93198

Sanivada UK, Mármol G, Brito FP, Fangueiro R (2020) PLA composites reinforced with flax and jute fibers-a review of recent trends, processing parameters and mechanical properties. Polymers 12:2373. https://doi.org/10.3390/polym12102373

Shahabi-Ghahfarrokhi I, Goudarzi V, Babaei-Ghazvini A (2019) Production of starch based biopolymer by green photochemical reaction at different UV region as a food packaging material: Physicochemical characterization. Int J Biol Macromol 122:201-209. https://doi.org/10.1016/j.jibiomac.2018.10.154

Silva JA, Tobella LM, Becerra J, Godoy F, Martinez MA (2007) Biosynthesis of poly- $\beta$-hydroxyalkanoate by Brevundimonas vesicularis LMG P-23615 and Sphingopyxis macrogoltabida LMG 17324 using acid-hydrolyzed sawdust as carbon source. J Biosci Bioeng 103:542-546. https://doi.org/10.1263/jbb.103.542

Sirohi R, Gaur VK, Pandey AK, Sim SJ, Kumar S (2021a) Harnessing fruit waste for poly-3-hydroxybutyrate production: a review. Bioresour Technol 326:124734. https://doi.org/10.1016/j.eti. 2020.101271

Sirohi R, Pandey JP, Tarafdar A, Agarwal A, Chaudhuri SK, Sindhu $R$ (2021b) An environmentally sustainable green process for the utilization of damaged wheat grains for poly-3-hydroxybutyrate production. Environ Technol Innov 21:101271. https://doi.org/ 10.1016/j.biortech.2021.124734

Souza AC, Goto GEO, Mainardi JA, Coelho ACV, Tadini CC (2013) Cassava starch composite films incorporated with cinnamon essential oil: antimicrobial activity, microstructure, mechanical 
and barrier properties. LWT 54:346-352. https://doi.org/10. 1016/j.lwt.2013.06.017

Spiridon I (2020) Extraction of lignin and therapeutic applications of lignin-derived compounds. A review. Environ Chem Lett 18:771-785. https://doi.org/10.1007/s10311-020-00981-3

Statista (2020) Annual production of plastics worldwide from 1950 to 2020. https://www.statista.com/statistics/282732/global-produ ction-of-plastics-since-1950/ (accessed on 3 July 2021)

Suresh A, Alagusundaram A, Kumar PS, Vo DVN, Christopher FC, Balaji B, Viswanathan V, Sankar S (2021) Microwave pyrolysis of coal, biomass and plastic waste: a review. Environ Chem Lett. https://doi.org/10.1007/s10311-021-01245-4

Suryawanshi Y, Sanap P, Wani V (2019) Advances in the synthesis of non-isocyanate polyurethanes. Polym Bull 76:3233-3246. https://doi.org/10.1007/s00289-018-2531-7

Syafiq R, Sapuan SM, Zuhri MYM, Ilyas RA, Nazrin A, Sherwani SFK, Khalina A (2020) Antimicrobial activities of starch-based biopolymers and biocomposites incorporated with plant essential oils: a review. Polymers 12:2403. https://doi.org/10.3390/polym 12102403

Tarrahi R, Fathi Z, Seydibeyoğlu MO, Doustkhah E, Khataee A (2020) Polyhydroxyalkanoates (PHA): from production to nanoarchitecture. Int J Biol Macromol 146:596-619. https://doi.org/10.1016/j. ijbiomac.2019.12.181

Tey WS, Cai C, Zhou K (2021) A comprehensive investigation on $3 \mathrm{D}$ printing of polyamide 11 and thermoplastic polyurethane via multi jet fusion. Polymers 13:2139. https://doi.org/10.3390/ polym 13132139

Thakur R, Pristijono P, Scarlett CJ, Bowyer M, Singh SP, Vuong QV (2019) Starch-based films: major factors affecting their properties. Int J Biol Macromol 132:1079-1089. https://doi.org/10. 1016/j.ijbiomac.2019.03.190

The Guardian (2020) Microplastics revealed in the placentas of unborn babies. https://www.theguardian.com/environment/2020/dec/22/ microplastics-revealed-in-placentas-unborn-babies (accessed 2 August 2021)

Tofa TS, Kunjali KL, Paul S, Dutta J (2019) Visible light photocatalytic degradation of microplastic residues with zinc oxide nanorods. Environ Chem Lett 17:1341-1346. https://doi.org/10.1007/ s10311-019-00859-z

Tutoni G, Becker ML (2020) Underexplored stereocomplex polymeric scaffolds with improved thermal and mechanical properties. Macromolecules 53:10303-10314. https://doi.org/10.1021/acs. macromol.0c01468

Ulery BD, Nair LS, Laurencin CT (2011) Biomedical applications of biodegradable polymers. J Polym Sci b: Polym Phys 49:832-864. https://doi.org/10.1002/polb.22259

Utami R, Khasanah LU, Manuhara GJ, Ayuningrum ZK (2019) Effects of cinnamon bark essential oil (Cinnamomum burmannii) on characteristics of edible film and quality of fresh beef. Pertanika J Trop Agric Sci. https://doi.org/10.1088/1757-899X/193/1/ 012057

Valappil SP, Misra SK, Boccaccini AR, Roy I (2006) Biomedical applications of polyhydroxyalkanoates, an overview of animal testing and in vivo responses. Exp Rev Med Dev 3:853-868. https://doi. org/10.1586/17434440.3.6.853

Verma R, Vinoda KS, Papireddy M, Gowda ANS (2016) Toxic pollutants from plastic waste- a review. Proc Environ Sci 35:701-708. https://doi.org/10.1016/j.proenv.2016.07.069

Vethaak AD, Leslie HA (2016) Plastic debris is a human health issue. Environ Sci Technol 50:6825-6826. https://doi.org/10.1021/acs. est. 6 b02569

Volova T, Shishatskaya E, Sevastianov V, Efremov S, Mogilnaya O (2003) Results of biomedical investigations of PHB and PHB/ PHV fibers. Biochem Eng J 16:125-133. https://doi.org/10.1016/ S1369-703X(03)00038-X

Wang Z, Qin Y, Li W, Yang W, Meng Q, Yang J (2019) Microplastic contamination in freshwater: first observation in Lake Ulansuhai, Yellow River Basin, China. Environ Chem Lett 17:1821-1830. https://doi.org/10.1007/s10311-019-00888-8

Xavier JR, Babusha ST, George J, Ramana KV (2015) Material properties and antimicrobial activity of polyhydroxybutyrate (PHB) films incorporated with vanillin. Appl Biochem Biotechnol 176:1498-1510. https://doi.org/10.1007/s12010-015-1660-9

Xiong YC, Yao YC, Zhan XY, Chen GQ (2012) Application of polyhydroxyalkanoates nanoparticles as intracellular sustained drugrelease vectors. J Biomater Sci Polym Ed 21:127-140. https:// doi.org/10.1163/156856209X410283

Yaradoddi JS, Banapurmath NR, Ganachari SV, Soudagar MEM, Mubarak NM, Hallad S, Hugar S, Fayaz H (2020) Biodegradable carboxymethyl cellulose based material for sustainable packaging application. Sci Rep 10:21960. https://doi.org/10. 1038/s41598-020-78912-z

Yu J, Chen LXL (2008) The greenhouse gas emissions and fossil energy requirement of bioplastics from cradle to gate of a biomass refinery. Environ Sci Technol 42:6961-6966. https://doi. org/10.1021/es7032235

Yu LP, Yan X, Zhang X, Chen XB, Wu Q, Jiang XR, Chen GQ (2020) Biosynthesis of functional polyhydroxyalkanoates by engineered Halomonas bluephagenesis. Metab Eng 59:119-130. https://doi. org/10.1016/j.ymben.2020.02.005

Yun J, Fan X, Li X, Jin TZ, Jia X, Mattheis JP (2015) Natural surface coating to inactivate Salmonella enterica serovar Typhimurium and maintain quality of cherry tomatoes. Int J Food Microbiol 193:59-67. https://doi.org/10.1016/j.ijfoodmicro.2014.10.013

Zierdt P, Theumer T, Kulkarni G, Däumlich V, Klehm J, Hirsch U, Weber A (2015) Sustainable wood-plastic composites from bio-based polyamide 11 and chemically modified beech fibers. Sustain Mater Technol 6:6-14. https://doi.org/10.1016/j.susmat. 2015.10.001

Publisher's Note Springer Nature remains neutral with regard to jurisdictional claims in published maps and institutional affiliations. 